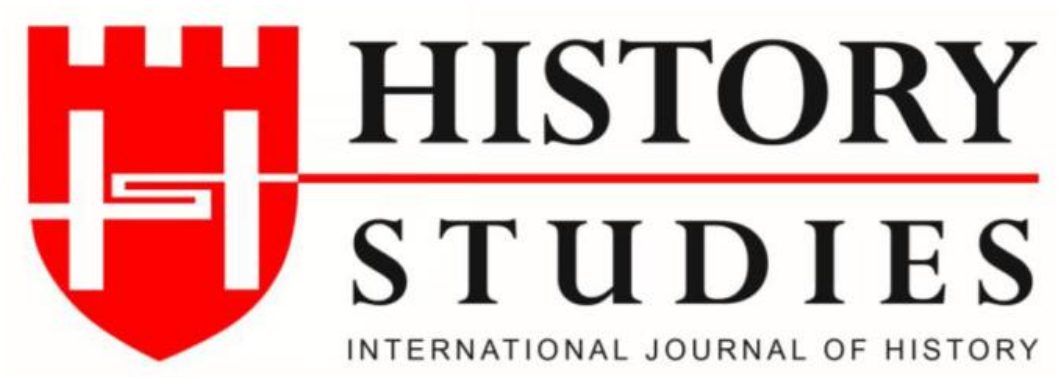

ISSN: 13094173 (Online) 1309 - 4688 (Print)

Volume 12 Issue 4, August 2020

DOI Number: 10.9737/hist.2020.913

Araştırma Makalesi

Makalenin Geliş Tarihi: 20.06.2020 Kabul Tarihi: 05.07.2020

Atıf Künyesi: Ali Naci Özyalvaç, “Konya Sultan Selim ve İstanbul Yavuz Sultan Selim Camileri'nde

Oran Araştırması ve Müellif Mimar Meselesi", History Studies, 12/4, Ağustos 2020, s. 2117-2141.

\title{
Konya Sultan Selim ve İstanbul Yavuz Sultan Selim Camileri'nde Oran Araştırması ve Müellif Mimar Meselesi
}

\author{
Ratio Use in Design of Konya Sultan Selim (Süleymaniye) and Istanbul Yavuz Sultan \\ Selim Mosques and Author Artist Issue
}

\author{
Dr. Ali Naci Özyalvaç \\ ORCID No: 0000-0001-5596-0146 \\ Necmettin Erbakan Üniversitesi
}

Öz: Konya'daki Osmanlı Devri Mimari eserleri içinde önemli yeri olan Sultan Selim Camii’nin müellifinin kimliği konusundaki farklı görüşlerin, yapıların boyut özellikleri, kullanılan elemanların biçimlenişleri ve tasarımda oran kullanımı başlıkları temel alınarak irdelenmesi, bu çalışmanın konusunu oluşturmaktadır. Sinan dönemi eseri olmakla birlikte, önceki devir yapıları ile kitle kuruluşundaki benzerlikler sebebi ile alanın uzmanları tarafindan saray mimarları ocağı başmimarı Alaeddin Ali Bey'e maledilen yapının, bu mimarın olduğu kabul edilen İstanbul'daki Yavuz Sultan Selim Camii ile biçim özellikleri bakımından bir karşılaştııılması yapılmaktadır. Her iki yapı için literatürde müellif mimar konusu aydınlığa kavuşmuş değildir. Burada ilk kez bir yöntem olarak yapıların kullanılan kemer tiplerinin tespit edilerek birbirleri ile ve dönemi içinde bilinen diğer yapılar ile kıyaslaması yapılmaktadır. Daha sonra plan ve kesit düzlemlerinde oran kullanımı konusu ele alınarak her iki yapının tasarım yaklaşımındaki benzer tutum analitik olarak ortaya konmaktadır. Yazılı kaynakların yetersiz kaldığı bu gibi durumlarda konunun yeniden ele alınabilmesi için doğrudan ayakta olan yapılara müracaat edilmesi yolu yöntem olarak önemlidir. Bu şekilde tekil yapı monografilerinde bilinmeyen hususların aydınlatılması yanında dönemi içinde uygulanmış tasarım yaklaşımlarının ortaya çıkartılmasına da katkı sağlanmaktadır. Sinan öncesi Klasik Osmanlı Mimarisi'nin önemli eserleri için bu çalışmanın sürdürülmesi önerilmektedir. Çalışmanın neticesinde bu iki yapının aynı müellif sanatçının eseri olduğu görüşünün gerçek olma ihtimali çok yüksek bulunmuş, bu sorgulama sırasında ilk kez fark edilen Sinan öncesi Osmanlı mimarlığında oran kullanımı konusunda yeni çalışmalara olan ihtiyaç ortaya çıkmıştır.

Anahtar Kelimeler: Konya Sultan Selim Camii, İstanbul Yavuz Selim Cami, Altın Oran, Sivri Kemer, Müellif. 
Abstract: The subject of this study is to examine different views on the identity of the author of the Sultan Selim Mosque, which has an important place in the Ottoman period architectural works in Konya, based on the dimensional properties of the structures, the shaping of the elements used and the ratio usage in design. A comparison is made with İstanbul Yavuz Selim Mosque and Konya Sultan Selim Mosque in terms of form features, because both buildings were attributed to the chief architect Alaeddin Ali Bey by the experts of the area. The author architect has not been clarified in the literature for the both of the buildings. Here, for the first time as a method, the types of arches used are determined and compared with each other and with other mosques known during the period. Then, by considering the ratio use in plan and section planes, the similar attitude in the design approach of both buildings is analyzed analytically. In such cases, where written resources are insufficient, it is important as a method to apply directly to standing structures in order to reconsider the issue. In this way, besides the clarification of the issues unknown in the monographs of the single buildings, it also contributes to the reveal of the design approaches applied during the period. It is recommended to continue this method of inquiry for important works of classical Ottoman architecture before chief Architect Sinan. As a result of the study, the accuracy of the view that the two mosques are the work of the same artist has appeared strongly, and the necessity for further studies has emerged on the use of ratio in Ottoman architecture before Sinan, which was first noticed during this questioning.

Keywords: Konya Sultan Selim Mosque, İstanbul Yavuz Selim Mosque, Golden Ratio, Pointed Arch, Authorship.

\section{Giriş}

Konya şehir merkezinde, Mevlânâ Celâleddîn Rûmî’nin kabrinin bulunduğu Mevlevî dergâhının batısında yer alan Sultan Selim veya önceki dönem kaynaklarda geçen ismi ile Süleymaniye Camii klasik devir Osmanlı Mimarisi'nin yöredeki en önemli örneğidir. Sultan II. Selim'in Konya'da sancak beyi olarak görev yaptığı ve babası Kanuni Sultan Süleyman'ın hükümdarlığı zamanında yapımına başlandığı yönünde tarihi kayıtlar bulunan eserin tam olarak yapım yılı ve müellifi bilinmemektedir. Bu denli önemli bir külliyenin parçası olarak benzersiz konumu yanında selatin camii vasfına sahip eserin yapımına ilişkin bilgilerin detaylı olarak açıklığa kavuşturulmamış olması tahminlerin yürütülmesine sebep olmuştur. Yapının Mimar Sinan döneminde inşa edilmiş oluşu, başmimarlığı sürerken önemli bir vilayette inşa edilen bu selatin camii'nin ona atfedilmesine sebep olmuş, ancak Sinan'ın eserlerinin listesini veren yazmalarda kaydının bulunmayışı diğer ihtimalleri gündemde tutmuştur. Aynı zamanlarda II. Selim'in Konya Karapınar'da inşa edilmesine vesile olduğu diğer bir yapı grubunun müellifinin burada görev almış olabileceği düşüncesi ile iki yapının benzerlikleri konusu ortaya çıkmıştır. Diğer bir iddia ise yapının Sinan öncesi Hassa Mimarları Ocağı başmimarı Alâeddin Ali Bey (Acem Ali'si) tarafından yapılmış olduğudur ki hem eserin ihtiva ettiği klasik öncesi dönemi hatırlatan kitle özellikleri hem de bu müellifin diğer yapılarını inceleyen kişiler tarafından benzerlikler olduğu yönündeki yorumlar bu iddiaya destek vermektedir. Daha önceki çalışmalarımızda öncelikle yapının Mimar Sinan'ın başmimarlığı döneminde başkent İstanbul'da inşa edilen 19 cami ile biçim özellikleri ve sivri kemer biçimlenişleri bakımından 
kıyaslaması yapılmış idi. ${ }^{1}$ Orada elde ettiğimiz bulgular yanında yapının diğer yapılarda eşine az rastlanan bir oran kurgusuna sahip olduğu ve tasarımında yatay ve düşey plan düzlemlerinde altın kesim gibi yöntemlerin tititzlikle uygulanmış olduğu ortaya çıkmıştı. Burada konuyu farklı yönleri ile ele almak zarureti doğmaktadır. Yapıda kullanılan kemerlerin tiplerinin belirlenmesi ile bu tiplerin çağdaşı olan diğer eserlerde kubbe altında, mahfil altlarında, duvar payandalarının ve açıklıkların üzerinde, avlu ve son cemaat yeri revaklarında kullanımlarını tetkik ve tespit etmek yoluyla eseri bir devamlılık içine yerleştirmek önceki makalemizde izlediğimiz yöntem olmuştur. Osmanlı mimarlığında, daha özelde klasik dönem ve İstanbul'da Mimar Sinan dönemi camilerinde altın oran'ın varlığı ve kullanımı konusu hakkında yapılmış çalışmalar bulunmaktadır. Aynı şekilde Anadolu Türk Mimarlığında daha önceden beri kullanılmakta olduğu da ortaya konmuştur. ${ }^{2}$ Ancak Konya Sultan Selim Camii'nin müelliflik yaklaşımı bakımından kıyaslama yapılabilmesi için diğer önemli yapıların benzer başlıklar altında tasnif edildiği bir envanter dökümü bulunmamaktadır. Bu çalışma kapsamında ilk hedeflenen Konya Sultan Selim Camii'nde yatay ve düşey plan düzlemlerinde oran kullanımını belgelemektir. Yapının karşılaştırması için İstanbul Yavuz Selim Camii'nin güncel rölöveleri kullanılarak biçimleniş özellikleri, mekân boyutları, kullanılan kemer tipleri ve oran kullanımı ayrıntılı olarak incelenmiş ve kıyas yapmayı mümkün kılacak veriler elde edilmiştir. Üst ölçekte Osmanlı mimarlığında klasik dönem özelliklerinin ortaya konduğu yapılar grubu içinde ortak tasarım kararlarının belirlenmesi, daha özelde Sinan devri başkent İstanbul'da önemli yap1 manzumelerinde kullanılan kemer tiplerinin kullanımında süreklilik ve değişimlerin izlenmesi, yapılar özelinde Konya Sultan Selim ve İstanbul Yavuz Sultan Selim Camii'lerinin tam aydınlatılmamış olan müellif sanatçı konusunun yapılara müracaat edilerek sorgulanması amaçlanmaktadır. $^{3}$

Mimar Alâeddin Ali Bey'in her iki yapının müellifi olduğu konusundaki iddiayı güçlendirecek yeni bulgular çalışmayı ayrıca anlamlı kılmaktadır. Kendisinin kısa bir zaman önce İran'dan getirilmesine rağmen başmimar yapıldığı şeklindeki eski anlatı, haklı olarak klasik dönemi hazırlayan önemli yapı manzumelerinin inşasını açıklamakta yetersiz kalmakta idi. Ancak güncel çalışmalar Alâeddin Ali Bey’in bilinenden uzun süre önce teşkilata dahil olmuş ve içeriden yetişmiş olduğunu ortaya çıkarmıştır. Bu sürekliliğin kurulması ile Sinan'ı da hazırlayan saray mimarlık okulunun tasarım yaklaşımlarındaki ortaklıkları aydınlatmak için İstanbul ve Edirne Bayezid Camii'leri gibi diğer yapıları da etüd ederek araştırmayı genişletme

\footnotetext{
${ }^{1}$ Ali Naci Özyalvaç, Konya Sultan Selim (Süleymaniye) Camii Biçim Özellikleri ve Müellif Mimar Meselesine Bir Katkı, Art-Sanat Dergisi, İstanbul Üniversitesi Türkiyat Araştırmaları Enstitüsü, 2020. (Yayın aşamasında)

${ }^{2}$ Konu ile ilgili yayınlardan bazıları için bkz. Orhan Cezmi Tuncer, "Orantı ve Modül Üzerine Selçuklu Yapılarından Bazı Örnekler", Vakıflar Dergisi, S.13, 1981, s.449-488; Orhan Cezmi Tuncer, "İstanbul Edirnekap1 Mihrimah Sultan Camisi Geometrik Kurgusu”, Vakıflar Dergisi, S.33, 2010, s.113-124; Orhan Cezmi Tuncer, "Geleneksel Bazı Vakıf Yapılarımızda Duvar Kalınlıkları, Yükseklikleri, Açıklıkları Arasındaki Matematiksel Bağ ve Temeller Üzerine Bir İnceleme", Vakıf Haftası Dergisi, S.9, 1992, s.285-296; Orhan Cezmi Tuncer, "Modülasyondan Restorasyonlarda Yararlanma", Vakıf Haftası Dergisi, S.2, 1985, s.95-99; Aptullah Kuran, "Mimar Sinan Yapısı Karapınar II. Selim Camiinin Proporsiyon Sistemi Üzerinde Bir Deneme", VII. Türk Tarih Kongresi Bildiriler Kitabı, C.2, Ankara 1970, s.711-716; Orhan Cezmi Tuncer, "Vakıf Yapılarında Estetik Kavramlar", Vakıflar Dergisi, S.43, 2015, s.149-172; Orhan Cezmi Tuncer, Anadolu Selçuklu Mimarisi ve Moğollar, Vakıflar Bankası, Ankara, 1986.

${ }^{3} \mathrm{Bu}$ karşılaştırmaları mümkün kılacak, diğer yapıların yer aldığı çalışmalar hakkında daha detaylı bilgi için bkz. Ali Naci Özyalvaç, İstanbul'da Mimar Sinan Camilerinde Sivri Kemer Biçimlenişleri, (Yayımlanmamış Doktora Tezi, Yıldız Teknik Üniversitesi Fen Bilimleri Enstitüsü), İstanbul, 2017.
} 
gerekliliği görülmektedir. Aşağıda bu yönde atılan bir adım olarak Konya ve İstanbul Sultan Selim Camileri'nin kemer tipleri belgelenmiş ve kıyaslaması yapılmış, ayrıca yeni bir başlık olarak oran kullanımı bakımından iki yapı birlikte değerlendirilmiştir.

\section{Konya Sultan Selim Camii’nin Kısa Tarihçesi ve Farklı Görüsşler}

Cami daha sonra yapı grubuna eklenen Sultan Selim imareti sebebiyle bugün Sultan Selim Camii veya Selimiye Camii olarak anılsa da kaynaklarda Cami-i Cedid veya Cami-i Şerif-i Sultan Süleyman olarak geçmektedir. ${ }^{4}$ İbrahim Hakkı Konyalı'ya göre caminin inşasına Sultan Süleyman'ın sağlığında başlanmış ve kendisinin vefatından sonra oğlu II. Selim tarafından tamamlanmıştır. İlk zamanlarında Yeni Cami adı verilen eserin III. Murad zamanında Sultan Süleyman Camii şeklinde geçtiğini söyleyen yazar dönemin yazılı kaynaklarında bu bilgiyi teyit eder. ${ }^{5}$ Kanuni Sultan Süleyman devrine ait belgelerde caminin yapımına ilişkin bilgiler bulunması yapının bu padişah tarafından yapıldığı şeklinde yorumlanmıştır. ${ }^{6}$ Diğer bir kısım araştırmacı yapının banisi olarak Konya sancak beyliği yapan Sultan Süleyman'ın oğlu Şehzade II. Selim'i görtermektedir.

Eyice, yapıyı Mimar Sinan ve takipçileri dönemi içinde ele almış ve Yavuz Sultan Selim adına XVI. yüzyılın ilk yarısında yapılan eserin bir kubbe ve yarım kubbe düzeniyle ilk Fatih Camii mimarisinin adeta aynen tekrarladığını yazmıştır. ${ }^{7}$ Mimarına ilişkin bilgi sahibi olmadığımız yapı ile ilgili Mimar Sinan, Sinan öncesi Hassa Ocağı'nın başında bulunan Mimar Acem Ali'si olarak da bilinen Alâeddin Ali Bey veya yukarıda sözü edilen Halepli Mimar Cemâleddin isimleri ile karşılaşmaktayız. Ayrıca yapı plan özellikleri bakımından Hammer tarafından Ayasofya Camii ile kıyaslanmıştır. ${ }^{8}$ Şahabettin Uzluk ise eski Fatih Camii örnek alınarak yapıldığını iddia etmiştir. ${ }^{9}$ Konyalı da birçok diğer yazar gibi Matrakçı Nasuh'un ünlü eseri Beyân-1 Menâzil-i Sefer-i Irâkeyn'de Konya'nın XVI. yüzyıl ilk çeyreğini gösteren resimlerinde Mevlânâ külliyesinin bulunduğu mevkide caminin olmadığını, türbe, tek minareli mescid, hatta şadırvan ve avlu duvarlarının seçilebildiği halde iki minareli Süleyman Camii'nin resmedilmeyişinden hareketle yapının bu tarihte mevcut olmadığını kabul etmek gerektiğini belirtmiştir. ${ }^{10}$ Aslanapa, Osmanlı Devri Mimarisi’nde, Konya Sultan Selim Camii’ni II. Selim'im ilk yıllarında yapılan camiler arasında sayar ve Selim'in şehzadeliği sırasında yapımına başlanılan eserin padişahlığının ilk yıllarında, 1566 ' da tamamlandığını belirtir. ${ }^{11}$ Yine Konya'daki en önemli Osmanlı mimarisi ürünü olarak gösterdiği yapının Eski Fatih Camii'nin abidevi ölçülerde yeniden ele alındığı klasik dönemin önemli bir ürünü olduğunu söyler. Yapının II. Selim tarafından babası adına yaptırıldı̆̆ 1 için kendi adına kitabe koydurmadığını ifade eden Aslanapa, yapının müellifi konusunda Mimar Sinan'ın o dönemde Hassa mimarlarının başı olduğu halde tezkerelerde yapı adının geçmediğini, bu dönemde yapılan bir

\footnotetext{
${ }^{4}$ Yusuf Küçükdağ, "Sultan Selim Camii ve Külliyesi”, TDVIA, C.37, İstanbul 2009, s.516

${ }^{5}$ İbrahim Hakk1 Konyal1, Âbideleri ve Kitâbeleri ile Konya Tarihi, Yeni Kitap Basımevi, Konya 1964, s.194.

${ }^{6}$ Ankara Vakıflar Genel Müdürlüğü Arşivi, 475 numaralı defter, s.7.

${ }^{7}$ Semavi Eyice, "Cami”, TDVIA, C.7, İstanbul 1993, s.80.

${ }^{8}$ Joseph Von Hammer-Purgstall, Devlet-i Osmâniyye Târihi (trc. Mehmed Atâ), C.3, İstanbul 1329-1337, s.95.

9 Şahabeddin Uzluk, “İstanbul'daki Eski Fatih Camii'nin Bir Benzeri Konya'da Selimiye Camii," Vakıflar Dergisi, S.9, 1971, s.177.

${ }^{10}$ Konyal1, age, s.195

${ }^{11}$ Oktay Aslanapa, Osmanlı Devri Mimarisi, İnk1lap Yayınları, İstanbul 2004, s.276.
} 
selatin camii'nin Sinan'ın ilgisinden kayıtsız olmasının mümkün olmadığını, yine de kişisel görüşü olarak dört duvar üzerinde oldukça ağır bir kitle halinde yükseltilen orta kubbenin Sinan'ın kıvrak üslubu ile uyumlu olmadığını kaydetmiştir. Sönmez, kitabeleri bulunmamasına rağmen üslup özellikleri ve yapım tarihleri dikkate alınarak Konya Sultan Selim Camii'ni Saraybosna Gazi Hüsrev Bey Külliyesi, Trabzon Hatuniye, Manisa Sultan, Çorlu Süleymaniye, Tekirdağ Saray Ayas Paşa, Fatih Bâli Paşa, Sütlüce ve Silivri Pirî Mehmet Paşa camileri ile birlikte Acem Ali olarak bilinen Alâeddin Ali Bey isimli Hassa başmimarına bağlamaktadır. ${ }^{12}$ Mimar Sinan'ın selefi olan Acem Ali'nin önemli eseri İstanbul Yavuz Selim Camii, kendi üslubunu eksiksiz ortaya koyduğu bir örnek olarak gösterilmiştir.

Aptullah Kuran da aynı şekilde yapının Sinan'ın öz yapıları arasında sayılmasının mümkün olmadığını iddia etmektedir. ${ }^{13}$ Eski Fatih ve Gözleve Tatar Han camilerinin plan şemasını tekrarlayan Konya Selimiye Camii'nin II. Bayezid ve Yavuz Sultan Selim dönemlerini hatırlatan keskin köşeli kitle kuruluşu ve uçları kapalı son cemaat revakına bakıldığında Sinan'ın 1560'lı yıllarda eriştiği mimari üslup ile bağdaştırmanın son derece güç olduğunu ifade eden yazar, Sultan Selim Camii'nin başka bir mimar tarafından yapılmış olması gerektiğini söyler. Necipoğlu'na göre caminin inşasına 1559 yılında Konya surlarının dışında padişahın iki şehzadesi Bayezid ve Selim arasında ortaya çıkan taht mücadelesinden kısa süre sonra başlanmış olması mümkündür ve inşa edilmesi sürecinin bu bağlamda ele alınması gerekliliğine vurgu yaparak İmparatorluk açısından çok önemli bu olay sonrasında yapımına başlanılan Süleymaniye Camii ve Karapınar'da Selim adına inşa edilen yapıların birer zafer anıtı, kutlu bir olayın nişaneleri olduğuna işaret eder. ${ }^{14}$ Nitekim Mustafa Âli de bu y1llarda

Volume 12

Issue 4

August

2020 Sultan Süleyman tarafından şeyhin nurlu kabri yanında kubbeli bir mescid, daha sonra 155960'ta türbesine bitişik kubbeli semâhâne ve dergâhın yanı başına iki minareli latif bir cami eklettiğini bildirir. ${ }^{15}$

Sultan II. Selim'in aynı tarihlerde Konya'nın Karapınar ilçesinde yaptırdığı imaretin mimar Halepli Cemâleddin tarafından yapıldığının ortaya çıkması sonrasında yakın zamanlı bu yapının da mimarı olarak görevlendirilmiş olduğu iddiaları gündeme gelmiştir. ${ }^{16}$ A. Kuran, Konya Karapınar ilçesinde bulunan II. Selim Camii'nin tezkerelerde kayıtlı olduğundan hareketle Sinan'ın önemli eserlerinden biri olduğunu, kitle kuruluşu, yatay ve düşey planlarda kusursuz oranları ile İstanbul'da tasarlanıp merkezden gönderilen yetenekli bir mimarın gözetiminde gerçekleştirildiği ifade etmektedir ancak cami için Halep kadısından Halepli Cemâleddin isimli mimarın acilen gönderilmesinin istenildiği, ancak yapının inşasının başlangıcından bitirilişine kadar Hassa mimarlarından Mimar Mehmed'in görevlendirildiği yönünde yeni belgeler ortaya çıkmıştır. ${ }^{17}$

\footnotetext{
${ }^{12}$ Zeki Sönmez, “Acem Ali”, TDVİA, C.1, İstanbul 1988, s.322.

${ }^{13}$ Aptullah Kuran, Mimar Sinan, Hürriyet Vakf1 Yayınları, İstanbul 1986, s.157.

${ }^{14}$ Gülru Necipoğlu, Sinan Çă̆ı: Osmanlı Imparatorluğu'nda Mimari Kültür, İstanbul Bilgi Üniversitesi Yayınları, İstanbul 2013, s.81.

${ }^{15}$ Âlî Mustafa Efendi, Künhü'l-Ahbâr, Nuruosmaniye Kütüphanesi, Ms.3409, 118b-119a.

${ }^{16}$ Yusuf Küçükdağ, Karapınar Sultan Selim Külliyesi, Karapınar Belediyesi Yayını, Konya 1997, s. 31-32.

${ }^{17}$ Abdülkadir Dündar, "Karapınar Sultan Selim Camii'nin Mimarı Hakkında Yeni Bir Kayıt", Türkiye Büyük Millet Meclisi'nin Açılışının 80. Yıldönümü Karapınar Sempozyumu, (ed. Yusuf Küçükdağ), Konya 2000, s.165-174.
} 


\section{Altın Oran ve Mimaride Kullanımı}

Yüzyıllar boyunca sanatta uyum ve proporsiyon bakımından en olgun değerleri verdiğine inanılan düzen bağıntısı olarak ifade edilen kavramın günümüzde sanatsal yaratma alanında etkileri yok denecek kadar az olsa da Rönesans döneminde çok ciddiye alınmış ve üzerinde çalışılmıştır. Bugün çağdaş sanat yaklaşımı uyum ve yaratma sorunsalını bu ve benzeri şekilde tek bir formüle indirgeyen ve kullanılabilecek bağıntılardan yalnız bir tanesi olarak benzeri yöntemleri yadsımaktadır. ${ }^{18}$ Modern dönem öncesinde altın oranın mimaride kullanıldığına dair bir kanıt bulunmadığını söyleyen Peker, mimarlık - geometri ilişkisi bağlamında konuya eleştirel yaklaşımların ortaya çıktığı 1980 sonrası dönemden günümüze fraktal geometri ve biyomimetik mimarlık akımlarının benzer arayışların devamı niteliğinde olduğunu belirmektedir. ${ }^{19}$

Altın oran, temelde ikiye bölünen bir bütünün parçaları arasındaki ilişki ile ilgilidir. Büyük ve küçük parçaların birbirine oranı ile bütünün büyük parçaya oranının birbirine eşit olduğu durumu ifade etmektedir ki bu sayısal olarak 1,618 değerine eşittir. Bir doğruyu ikiye bölen öyle bir nokta vardır ki ortaya çıkan küçük ve büyük parçalar arasında bu oran bulunmaktadır. İki kenarı arasında bu oran bulunan dikdörtgen için altın dikdörtgen, yine taban ve kenarları arasında bu oran bulunan ikizkenar üçgen için altın üçgen adlandırması yapılmıştır. Özellikle beşgen ve ondan üretilen yıldız şeklinde kendiliğinden bu oranların mevcut olması birçok sanat eserinin kuruluşunda tercih edilmelerine sebep olmuştur. Bu oranın varlığı estetik olarak üstünlük işareti olduğu ve insanların beğenisini kazanan orantıların bu değere yakın olduğu iddia edilmiştir.
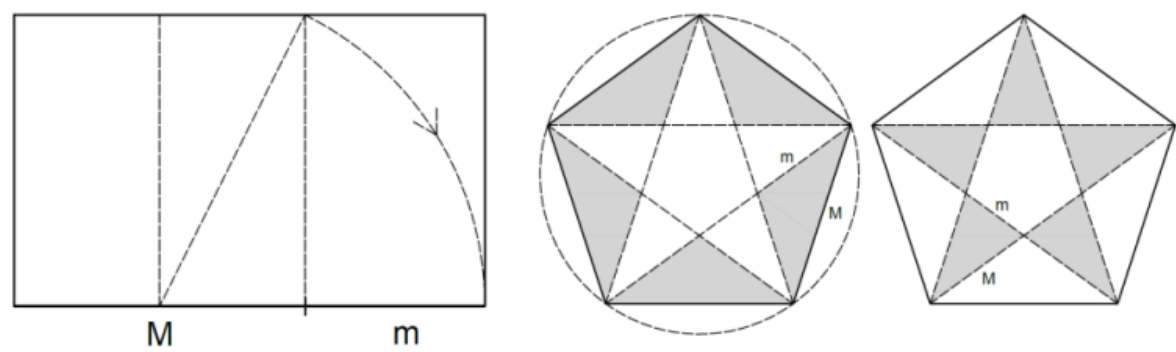

Volume 12

Issue 4

August

2020

Şekil 1 Solda Karenin alt kenarı ortasından pergel yardımıyla altın dikdörtgenin türetilmesi, Sağda beşgen ve beş kollu yıldız kullanılarak iki farklı altın üçgenin türetilmesi $(M / m=(M+m) / M)$

Matematiksel olarak bütün ve parçalar arasındaki bağıntının $\mathrm{a} / \mathrm{b}=\mathrm{b} /(\mathrm{a}+\mathrm{b})$ şeklinde yazılarak bu denklemin çözülmesinden $(\sqrt{5}+1) / 2$ değerine ulaşı1ır ki bu irrasyonel $\Phi$ (ünlü Yunan heykeltraş Phidias'ın adının baş harfi ile Phi) sayısı 1,618 ... şeklinde bulunur. Bu sayıya "altın sayı" da denmiştir. ${ }^{20}$ Ayrıca bu sayıya 1 eklendiğinde kendi karesi olan 2,618... ve 1 çıkarıldığında karekökü olan $0,618 \ldots$ sayısını vermesi bakımından kendine özgü ilginç durum oranın sayısal değerinde de görünür olur. İlginç biçimde Fibonacci dizisi olarak bilinen ve her sayının kendinden önceki iki sayının toplanması sonucu oluşan dizide sayılar birbirlerine

${ }^{18}$ Metin Sözen - Uğur Tanyeli, Sanat Kavram ve Terimleri Sözlüğü, İnkılap Kitapevi, İstanbul 1992, s.18.

${ }^{19}$ Ali Uzay Peker, "Altın Oran ve Mimarlık: Efsane ve Gerçekler: Mimarlık Altın Oran ilişkisi üzerine kısa bir yazı”, Boğaziçi Dergisi, Boğaziçi Üniversitesi Mezunlar Derneği, S.231, 2017, s.46-47.

${ }^{20}$ Mehmet Suat Bergil, Altın Oran, Arkeoloji ve Sanat Yayınlan, lstanbul 1993, s.3. 
bölündüğünde altın orana ulaşılır. 1, 1, 2, 3, 5, 8, 13, 21 ... şeklinde devam eden dizide değerler büyüdükçe aralarındaki oran 1,618 değerine yaklaşır. Yapı bölümleri arasında bu tam sayıların kullanılması ile kusursuz güzelliğe ulaşma çabası da uygulandığı bilinen diğer bir yaklaşımdır.

Altın kesim ya da altın oran birçok başka şekilde karşımıza çıkmaktadır. Geometrik olarak oluşturulmasının basitliği kullanım kolaylığı açısından teorik tartışmaların ötesinde yaygın bir biçimde başvurulmasında en önemli etkendir. Bir karenin altın dikdörtgene tamamlanması yalnızca karenin alt kenarının ortasını merkez alan bir yayın pergel ile çizilmesi ile mümkün olabilir. Ayrıca oluşturulan bu altın dikdörgen içinden her bir kare eksildiğinde yine geriye altın dikdörtgen kaldığı için, alt ve üst boyutlarda tümü birbiri ile orantılı birçok değerin üretilmesi de kendiliğinden bir dizi oluşturmaktadır. Beşgen kullanımı yine altın orana sahip üçgenlerin kurulması için basit bir geometrik yöntem sunmaktadır. Bu iki özellik; yani geometrik olarak basit birkaç hamlede üretilebilir olması ve fraktal olarak tümü birbiri ile oranlı daha küçük ve daha büyük değerlerin aynı mekanizma ile elde edilebilmesi nitelikleri ile altın oran, kökenine ilişkin felsefi ve teorik diğer tüm başlıkların ötesinde plastik sanatlarda bütünlüğü sağlamak konusunda başvurulan temel prensiplerden biri olagelmiştir. Bunun yanında doğada, müzikte ve insan vücudunda bulunan oranlar ile yakın ilişkili olduğu öne sürülmüştür. Antik Çağ'dan bu yana matematikçiler, düşünürler ve sanatçılar tarafından ele alınan bu olgu altın oran ismini 19. yüzyılda almıştır. ${ }^{21}$ Eski Yunanlar bu orana kısaca "bölüm" demişlerdir. İtalyan matematikçi Luca Pacioli "divina proportione" ve Leonardo Da Vinci tarafindan "sectio aurea" adı verilmiştir.

Altın oran Mısırlılar ve Yunanlar tarafından biliniyor ve mimaride, heykel ve diğer sanat yapıtlarının üretiminde kullanılıyordu. Antik Yunanlı düşünürler doğada kendiliğinden bulunan ve insan eliyle yaratılan her çeşit güzelliğin temelinde matematik ilişkiler bulunduğu görüşünden hareketle oran kavramı üzerinde düşünmüş ve özellikle Pisagorcu filozoflar güzelliğin ve uyumun matematiksel kaynağı ile evrendeki düzen arasında bir bağlantı olduğunu iddia etmiştir. ${ }^{22}$ Altın oran araştırmaları Pisagorcular'ın beş köşeli yıldız veya pentagram üzerine yaptıkları çalışmalardan ortaya çıkmıştır ve bununla birlikte mimarlık için metafizik nitelikte bir dönem başlamış, mimari; zamansız kurallar tarafından yönetilen matematiksel bir yapı olarak görülmüştür. ${ }^{23}$ Platon ve öğrencisi Aristoteles'e göre bütün güzelliklerin sebebi formlardır ve tek belirleyicisi sayı ve sayılar arası orantıdır. Buradan hareketle matematik bir olgu olarak güzellik, matematik olarak belirlenebilirdir. ${ }^{24}$ Misır kültüründe 3:4:5 üçgeni olarak bildiğimiz üçgenden yararlanıldığı ve kutsallık atfedildiği bilinmektedir. Yine altın oran ilkesine göre kurulan üçgen, dörtgen ve prizmaların çok sayıda örnek üzerinden tapınak, mezar ve piramit gibi yapıların tasarımında kullanıldıkları iddia edilmiştir. ${ }^{25}$ Antik Pers mimarlığında modül uygulaması ve eşkenar üçgenin cephe tasarımında tercih edildiği gösterilmiştir. ${ }^{26}$ Yunan sanatında da modül anlayışı ile, örneğin bir sütun çapını temel ölçü kabul ederek bu modülün katları ile diğer ölçülerin türetilmesi metodu kullanılırdı. Vitrivius, "Mimarlık Üzerine On

${ }^{21}$ Mete Tapan, “Altın Oran”, Eczacıbaşı Sanat Ansiklopedisi, YEM Yayın, C.1, İstanbul 1997, s.75.

${ }^{22}$ Doğan Kuban, Mimarlık Kavramlarl, Yapı Endüstri Merkezi Yayınları, İstanbul 1990, s.54.

${ }^{23}$ Roberto Masiero, Mimaride Estetik, Dost Kitabevi Yayınları, Ankara 2006, s.40.

${ }^{24}$ İsmail Tunali, Grek Estetik'i, Remzi Kitabevi, İstanbul 1983, s.57.

${ }^{25}$ Bergil, age, s.117.

${ }^{26}$ Behçet Ünsal, Mimari Tarihi, I.D.M.M.A. Yayınları, İstanbul 1973, s.202. 
Kitap" adlı eserinde klasik düzenler içinde doğru ve kusursuz tapınaklar yapılabilmesi için gereken oran sistemlerini detaylı olarak anlatmış, yine benzer şekilde Palladio'da kendi kitabında sütun çapını modül kabul eden aynı yaklaşımı tekrarlamıştır. ${ }^{27}$ Yunanlı düşünürler özellikle tam sayıların birbirleri ile oranından hareketle ortaya koydukları notalar ile kurdukları müzik sisteminin matematiğin güzellik ve evrendeki düzen ile ilişkisi bağlamında en büyük başarı olduğunu, ayrıca müziğin matematiksel oranlara indirgenebileceği gerçeğinin diğer bilimler için de geçerli sayılabileceğini düşünüyorlar ve bu (1:2, 2:3 gibi) tamsayı oranlarını mimaride de uyguluyorlardı. Rönesans sanatçılarına göre mimarlık bir bilim olarak matematikteki sayılar arasındaki orantıda olduğu gibi yapının içindeki ve dışındaki her parçasının bütün ile arasındaki uyumun peşinde olmuşlardır. Temel formların kullanımı ve yeni boyutların bu formların geometrik türevlerinin kullanımı ile (örneğin kare ve diyagonali gibi) tümü birbiri ile uyumlu bir dizi elde edilebiliyordu. Rönesans'ın önemli teorisyeni Alberti ünlü kitabında Vitrivius'u örnek alarak güzelliğin akıl ile algılanan bir düzen, kusursuz bütünlüğün hiçbir ekleme ve çıkarma yapılamayacak bir kompozisyon ve düzenleme ilkelerinin de yine müzikte kullanılan tam sayı oranlarına bağlı olduğunu söylemektedir. ${ }^{28} 19$. yüzyılda bu konuda bilimsel açıklama getirme çabasına giren düşünürlerden Alman psikolog Fechner deneysel estetik çalışmaları ile nesnel sonuçlara varmak istemiş, çok sayıda kişinin katıldığı anketler sonucunda altın kesim ve altın dikdörtgenin yüksek beğeni aldığı sonucundan hareketle, estetik alanında deneysel metodun kullanımının mümkün olduğunu savunmuştur. ${ }^{29}$ Mimarlık öğrencilerinin el kitaplarından Ernst Neufert'in başucu eserinde altın oran mimarlıkta temel bir ilke olarak sunulur. ${ }^{30}$ Modern dönemde mimarlık üretiminde ölçü araştırmaları konusunda öncülerden Le Corbusier'in Le Modulor (1948) kitabında önerdiği boyut dizisi, insan ölçüsü ve altın kesimden yola çıkılarak geliştirilmişti ve bu evrensel ilkeyi gündelik insan üretimleri için standart oluşturacak bir yönteme temel alıyordu. ${ }^{31}$

Türk-İslâm mimarisinde ritim, simetri ve oran unsurlarıyla birlik ve bütünlüğü sağlayan bir âhenk arayışı görülmektedir. Ancak yapılarda hangi orantı ilkelerine uyulduğu, mimari projelerin hangi esasa veya plana göre yapıldığı meselesi henüz tam anlamıyla çözümlenememiştir. En geniş anlamda mimari âhenk, yapının yüksekliği ile eni arasındaki orandır. Yunan ve Roma mimarisinde sütun çapı ile sütun yüksekliği arasındaki oran bir birim olarak alınmış, bu birim yapının bütün boyutları için ölçü esası (modül) kabul edilmiştir. Mimaride âhengi sağlayan önemli unsurlardan biri de ritimdir. Benzer veya eş birimlerin belirli aralıklarla düzenli biçimde tekrarlanmasının sağladığı bu hareket, İslâm mimarisinde kemer ve revak sıralarıyla elde edilir. Osmanlı mimarisinde basit ölçülere bağlı olarak âhenk yaratma endişesinin en belirgin örneği pencî kemer denilen formda görülür. Ancak belirli oranlara dayanılarak ortaya çıkarılan bu kemer türü klasik devirde âhenkli bir biçime ulaştırılmıştır. ${ }^{32}$

\footnotetext{
${ }^{27}$ Nüket Tuncer, Klasik Dönem Osmanlı Mimarisinde İç Mekân ve Cephelerde Oran, (Yııldı Teknik Üniversitesi Fen Bilimleri Enstitüsü Yayımlanmamış Doktora Tezi), İstanbul 1996, s.29.

${ }^{28}$ Leon B. Alberti, The Ten Books of Architecture (1755 Leoni Edition), Dover Publications Inc., New York 1986.

${ }^{29}$ Suut Kemal Yetkin, Estetik, Remzi Kitabevi, İstanbul 1947, s.16.

${ }^{30}$ Ernst Neufert, Yapı Tasarımı, Kelaynak Yayınevi, Ankara 1983, s.29.

${ }^{31}$ Le Corbusier, (Charles Edouard Jeanneret), The Modulor and Modulor 2, Birkhäuser, Basel 2000.

${ }^{32}$ Selçuk Mülayim, “Ahenk”, TDVIA, C. 1, İstanbul 1988, s.523.
} 

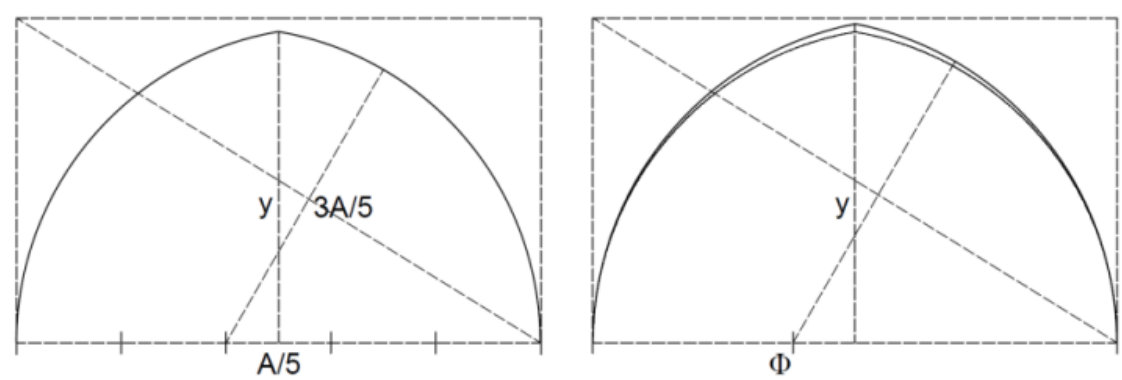

Şekil 2 Solda açıklığın 5'e bölünmesi ile kurulmuş iki merkezli beşlik (pencî) sivri kemer, sağda açıklığın altın kesim noktasından çizilen yaylar ile kurulmuş iki merkezli sivri kemer ve her ikisinin üzerinde altın dikdörtgen görülmektedir.

\subsection{Pencî Kemerin Altın Oran ile ilișkisi}

Pencî kemer olarak anlandırılan iki merkezli sivri kemer, açılığın 5'e bölünmesi (Farsça penc: beş) ile bulunan noktalardan ve açıklığın 3/5'i büyüklüğünde yarıçaplı daire yaylarının çizilmesi ile kurulan kemer tipidir. Örneğin açıklığın 5,00 m olduğu bir durumda merkezler arasında (1:5) oranına göre 1,00 m uzaklık bulunurken kemer yayları 3,00 m olur. Bu durumda kemerin altında kalan boşluğun tepe noktası, yani karın yayının üst noktası ile üzengi hattı arasındaki mesafe 2,95 m olur. Aynı kemeri açıklığı altın kesime göre ikiye bölerek bulduğumuz noktalardan çizdiğimizde ise merkezler arasındaki mesafe $1,18 \mathrm{~m}$ olur. Karın yayı tepe noktası ise merkez hattından 3,03 m yüksekliğe ulaşır. Yani ortalama büyüklüğe sahip bir pencî kemerde altın kesim ile bulunan noktalar ve (1:5) kuralına göre bulunan noktaların kullanılması kemer tepe noktasında $0,08 \mathrm{~m}$ gibi gözardı edilebilir bir değişikliğe sebep olmaktadır. Nitekim daha önce de söylendiği gibi Fibonacci dizisinde bulunan 3, 5, 8 gibi sayılar, değerleri büyüdükçe altın orana daha çok yaklaşmakta, buna rağmen tamsayılar olmaları bakımından hem antik devirlerden rönesans devrinde kadar müzik teorisinde hem de Le Corbusier gibi modern kuramcılar tarafindan mimaride tercih edildikleri bilinmektedir. Yine penci kemerin açıklığg üzerinden hareketle bir altın dikdörtgen çizilecek olursa, kemerin karın yayı tepe noktası ile dikdörtgenin yüksekliği arasında $5,00 \mathrm{~m}$ açıklıkta $0,13 \mathrm{~m}$ gibi bir fark oluşur. Bunun sebebi de beşlik (1:5) kemerin yükseklik / açıklık oranının 0,59 olmasına rağmen altın dikdörtgende bu oranın 0,61 olmasıdır. Tüm bu değerler bir arada değerlendirildiğinde estetik kusursuzluk arayışının uygulama kolaylığı ve tasarımda modülasyon ile birlikte ele alındığı anlaşılmaktadır.

\section{Konya Sultan Selim Camii Biçim Özellikleri ve Oran Araştırması}

Merkezî kubbeli plan şemasına sahip cami kareye yakın dikdörtgen harimi önünde yedi hücreli son cemaat yeri revakı olan iki minareli bir yapıdır. Merkezi kubbe, kıble yönünde bir yarım kubbe, doğu ve batı yönlerinde üçer küçük kubbenin örttügü harimde orta kubbeyi taşıyan iki bağımsız fil ayağı, ayaklar ile kuzey duvarına bitişik ayaklar arasında ikişer sivri kemerin oturduğu birer sütun bulunmaktadır. Kesme taştan yapılmış yapının mukarnas süslemeli cümle kapısından başka iki yanda birer kapısı daha vardır. Ortada merkezi kubbenin örttüğ̈̈ kare sahın 13,53 m (18,00 zira) kenar ölçüsüne sahipken, kıble yönünde yarım kubbe ile örtülmüş mihrap önü bölümü $6,05 \mathrm{~m}$ (8,00 zira), doğu-batı yönlerinde üçer kubbe ile 
örtülmüş yan sahınlar 6,60 m (9,00 zira) derinliğindedir. Doğu-batı yönündeki sivri kemerlerin plandaki $1,50 \mathrm{~m}$ (2,00 zira) izdüşümleri ile toplamda iç mekân doğu-batı yönünde $29,95 \mathrm{~m}$ (40,00 zira) dir. Son cemaat yeri revakları ana kütleden iki yanda 1,88 m (2,50 zira) taşma yaparak 37,50 m (50,00 zira) boyuna ulaşırken kubbe ile örtülü iki yan kanatta 3 hücre cümle kapısı aksındaki tonoz örtülü yüksek tavanlı hücreden daha küçüktür. Revak derinliği sütunları bağlayan sivri kemerlerin $0,75 \mathrm{~m}$ (1,00 zira) derinliği dahil 5,60 m (7,50 zira) dir. Kubbeyi taşıyan ayakları bağlayan mihrap yönündeki kemer 12,85 m (17,00 zira) açıklığa ve kilit taşı altından üzengi seviyesine $6,50 \mathrm{~m}$ (8,50 zira) yüksekliğe sahip daireye yakın iki merkezli sivri kemerdir. İç mekânda kıble yönündeki serbest ayaklar ile kuzeylerindeki sütunları bağlayan 8,00 zira $(6,00 \mathrm{~m})$ açıklığa ve planda 2,00 zira $(1,52 \mathrm{~m})$ derinliğe sahip kemerler açıklığın 5'e bölünmesi ile kurulmuş pencî (beşlik) kemerlerdir. Harimin doğu - batı cephelerinde küçük kubbelerin altında pencere ve kapıların üzerinde aynı kotta benzer beşlik sivri kemerler bulunur. Son cemaat yeri revakı ortada daha geniş ve yüksek, iki yanda üçer adet eş boyutlu olmak üzere iki yanda duvarlara ve ortada 6 sütuna oturan yedi sivri kemerle kurulmuştur. Cephede görülen ve sütunları kuzey duvarına bağlayan kemerlerin tümü açıklığın 7'ye bölünmesi ile bulunan noktalardan çizilen yaylardan oluşan iki merkezli yedilik sivri kemerlerdir. Yan birimlerin açıklığ 4,25 m (5,5 zira) ve ortada cümle kapısı aksını vurgulayan birimde kemer açıklığ yaklaşık $0,75 \mathrm{~m}$ (1,00 zira) daha büyük olup iki yandaki duvar kalınlı̆̆ 0,95 m (1,25 zira) ölçülmektedir.

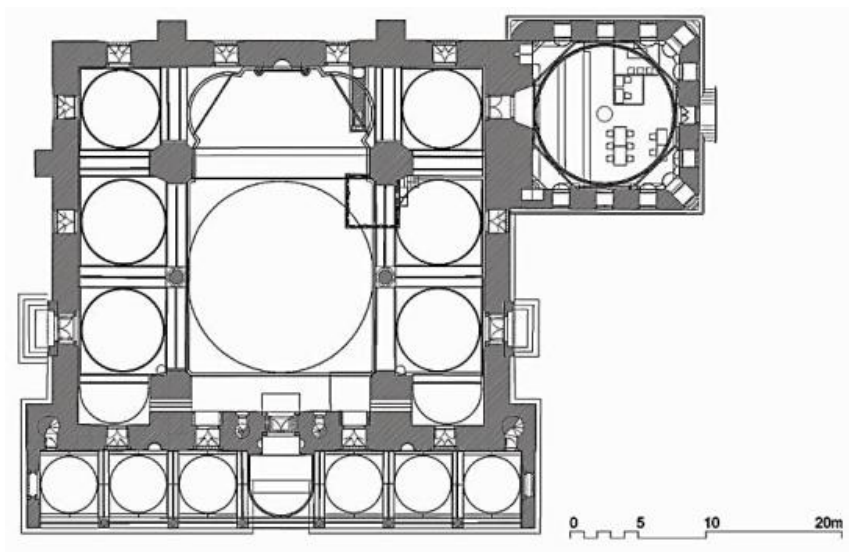

\section{Şekil 3 Konya Sultan Selim Camii Zemin Planı (Konya Vakıflar Bölge Müdürlüğü Arşivi, (30.06.2014) tarihli ve 2094 sayılı Konya Kültür Varlıklarını Koruma Kurulu onaylı Konya Sultan Selim Camii Restorasyon Projesi paftaları kurumdan resmi izin ile alınarak yazar tarafından sayısal ortamda düzenlenmiştir.)}

Yapının kemer tipleri ile mekân ve duvar kesit kalınlıkları gibi boyut özellikleri bakımından kıyaslanması daha önceden yapıldığı için burada oran kullanımı konusu ele alınacaktır. Kemer boyutları, revak hücrelerinin açıklık / yükseklik oranları, zemin kattaki dikdörtgen açıklıklı mermer söveli pencerelerin dış boyutları gibi başlangıçta tekrar ettiğini gördüğümüz oran kullanımı konusu detaylı olarak incelendiğinde yapının yatay izdüşüm düzleminde mekân boyutları ve üçüncü boyutta yüksekliklerin belirlenmesinde altın kesim, altın dikdörtgen ve üçgenlerin kullanılmış olduğu belirlenmiştir. Burada öncelikle yapının en temel biçim 
özellikleri olarak harimi sınırlandıran beden duvarlarının boyutları ve yapı heykelini oluşturan kitlelerin bir araya gelirken aralarındaki ilişki örnek olarak verilecektir. Daha sonra İstanbul Sultan Selim Camii ile karşlaştırma yapılabilmesi için benzer ve somut iki örnek olarak her iki yapıdaki son cemaat yeri ve avlu revakları daha detaylı olarak ele alınmaktadır. Cami zemin planında kuzey duvarı, yan duvarlar ve serbest ayakların yatay bileşeni ile sınırlanan dikdörtgenin boyutları 29,90 x 18,25 m olup 1,63 en / boy oranına sahiptir (Şekil 3, A). Giriş yönündeki ayaklar ile mihrap duvarı arasına çizilen dikdörtenin boyutları ise 22,50 x 13,95 m olup en boy oranı 1,61'dır (Şekil 3, B). Harim zemininden itibaren kubbenin başlangıç seviyesi yüksekliği $(+18,25)$ ve bu mesafenin altın kesime bölünmesi ile ana kitleye katılan kubbeli yan sahınların yükseklikleri $(+11,20)$ bulunmaktadır (Şekil 3, C). $(18,25 / 11,20 \mathrm{~m}=1,62)$ Harim zemin kotu $(-0,20)$ ile kubbe kilit taşı alt kotu $(+24,75)$ arasındaki düşey mesafe, sütun aksları arasındaki yatay uzaklık $(15,35 \mathrm{~m})$ ile sınırlandırılan dikdörtgenin en / boy oranı $(24,95$ / 15,35) 1,62'dir (Şekil 3, D). Yapıya doğu ve batı cephelerinden bakıldığında görülen yatay kitle, yani harimin kıble yönünde dıştan toplam ölçüsü $(30,05 \mathrm{~m})$ ile giriş sahanlığı $(-0,96 \mathrm{~m})$ ve kübik kitlenin üst noktası arasındaki yüksekliği $(18,56 \mathrm{~m})$ çevreleyen dikdörtgenin en / boy oranı 1,61'dir (Şekil 3, F). Yine yapı görünüşüne egemen olan ortadaki kübik kitlenin sınırları, cümle kapısı sahanlık kotu $(-0,96)$ ve minare külahı yüksekliği $(+35,50)$ ile sınırlanan dikdörtgenin boyutları arasında $(36,45$ / 22,60 m) 1,61 oran bulunmaktadır (Şekil 3, E). Son cemaat yeri revakı yan kanatlarda kubbe başlangıç seviyesi (kemer tepe noktası), kuzey beden duvarı ve sütunlar üzerindeki duvar dış yüzeyi ile belirtilen dikdörtgenin (Şekil 3, I) boyutları arasındaki ilişki $(9,28 / 5,73 \mathrm{~m})$ 1,62 yani altın oran nispetindedir.

Volume 12

Issue 4

August

2020

Harimin doğu ve batı cephelerine baktığımızda zeminde dikdörtgen açıklıklı mermer söveli pencereler, üstlerinde boşaltma kemerleri ve ikinci kat pencereleri, ayakları birbirine bağlayan sivri kemerlerin üzengi hatları ve tepe noktaları, beden duvarları içinde aynı kemerlerin tekrarı ve yan sahınların üstünü örten küçük kubbeler, yan giriş kapısının basık kemerli açıklığı ve kapıyı çevreleyen silme gibi elemanların düşeyde seviyeleri arasındaki ilişki incelenmiştir. Kubbe kilit taşı alt kotu altın kesime bölündüğünde yan kapı üst silmesi (Şekil 4, 7), sivri kemer tepe noktası altın kesime bölündüğünde kapı üzerindeki basık kemer tepe noktası (Şekil $4,8)$ bulunmaktadır. Benzer şekilde mermer söveli zemin kat pencerelerin üst seviyesi ile kemer boşluğu arasında, duvar kesiti içindeki pencere açıklığı seviyeleri ile beden duvarı yüksekliği arasında altın orana rastlanmaktadır. Matematiksel olarak bir modül kullanımına da işaret eden bu tasarım anlayışı, farklı birçok boyutun aynı kural ile türetilmesi sayesine ölçülerde çeşitliliğe imkân verirken büyüklükler arası nispetler sınırlı sayıda kalabilmektedir.

Konya Sultan Selim Camii son cemaat yeri revakında oran araştırması karşılaştırmaya esas olması açısından daha detaylı incelenmiştir. Merkezde girişi işaret eden biri daha geniş ve yüksek 7 hücreli son cemaat yeri, 6 sütuna ve iki başta duvara oturan 7 sivri kemerden oluşmaktadır. Son cemaat yeri yan kanat zemin kotu $(-0,33 \mathrm{~m})$ ile saçak kotu $(+8,42$ $\mathrm{m})$ arasındaki mesafe $(8,75 \mathrm{~m})$ altın kesimle bölündüğünde 5,35 $\mathrm{m}$ kemer üzengi seviyesi, aynı altın kesim ters kullanılır ise $(3,40 \mathrm{~m})$ duvar içinde zemin kat pencere boşluğunun üst sınırı olan $+2,98$ m kotuna ulaşılmaktadır (Şekil 5, 7 ve 8). Burada bir uzunluğun altın kesime uygun olarak bölünmesi ve en boy oranı altın kesime uygun dikdörtgenin yanında taban açıları $36^{\circ}$ ve $72^{\circ}$ derece olan ikizkenar üçgenlerin kullanıldığ görülmektedir. Beşgen kaynaklı bu iki 
üçgenin kenarları arasında altın oran bulunmaktadır ancak yükseklik / taban oranları taban açısı dar olanda 0,363 ve diğerinde 1,538 olarak iki yeni oran belirmektedir. Bu iki oranın her iki yapıda tekrar ettiği görülmektedir. Örneğin son cemaat yerinin en yüksek noktası olan orta hücre üst örtüsünün tepe noktası ile plandaki revak genişliği arasındaki ilişki ve her bir kemerin sütun aksları ile ilişkisinde bu iki üçgene rastlamaktayız. Orta ve yan hücrelerde sütun taban seviyesinde açıklık aksları, sivri kemer boşluğu tepe noktası arasına çizilen bir ikizkenar üçgenlerin kenarları arasındaki oran 1,618'dir (Şekil 5).

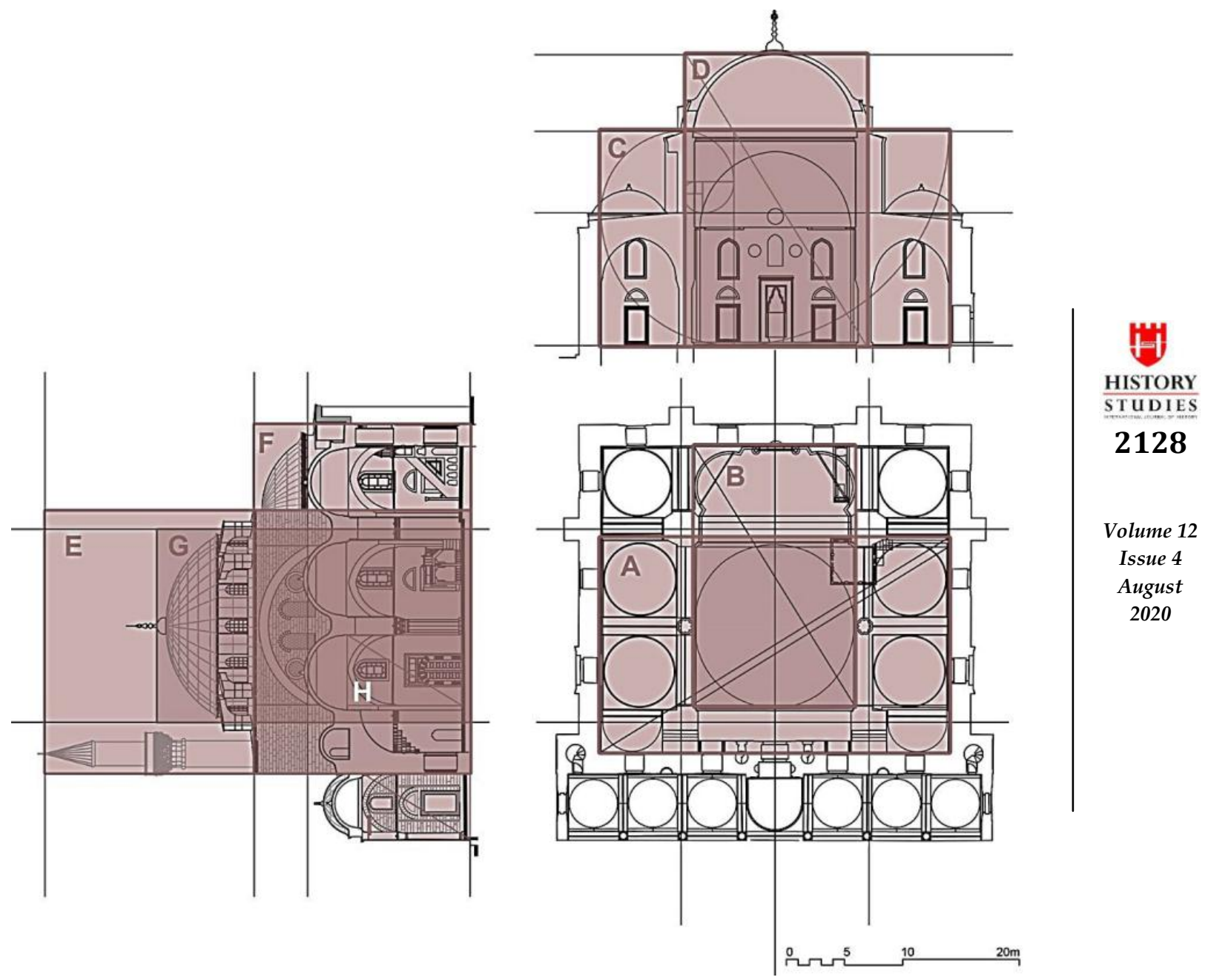

Şekil 4 Konya Sultan Selim Camii izdüşüm düzlemlerinde altın oranın kullanımı (Düzenlenen rölöve: VGM Arşivi)

Konya Sultan Selim Camii, plan ve kesit düzlemlerinde oran araştırması, [A] Cami zemin kat planında kuzey duvarı, yan duvarlar ve serbest ayakların yatay bileşeni ile sınırlanan dikdörtgenin boyutları 29,90 x 18,25 m olup 1,63 en / boy oranına sahiptir. [B] Giriş yönündeki ayaklar ile mihrap duvarı arasına çizilen dikdörtenin boyutları 22,50 x 13,95 m olup en boy oranı 1,61'dır. [C] Plandaki A dikdörtgeni düşey konuma getirildiğinde, harim zemininden itibaren kubbenin başlangıç seviyesi yüksekliği $(+18,25)$ ve bu mesafenin altın kesime bölünmesi ile ana kitleye katılan kubbeli yan sahınların yükseklikleri $(+11,20)$ bulunmaktadır. $(18,25 / 11,20 \mathrm{~m}=1,62)$ [D] Harim zemin kotu $(-0,20)$ ile kubbe kilit taşı alt kotu $(+24,75)$ arasındaki düşey mesafe, sütun aksları arasındaki yatay uzaklık $(15,35 \mathrm{~m})$ ile sınırlandırılan dikdörtgenin en / boy oranı (24,95 / 15,35) 1,62'dir. [E] Yapı görünüşüne

\section{History Studies}


egemen olan ve kemerler üzerinde yükselen kübik kitlenin sınırları, cümle kapısı sahanlık kotu $(-0,96)$ ve minare külahı yüksekliği $(+35,50)$ ile sınırlanan dikdörtgenin boyutları arasında $(36,45 / 22,60 \mathrm{~m})$ 1,61 oran bulunur. Bu yüksekliğin altın kesime göre bölünmesi ile (22,52 m ve 13,93 m) mihrap yönündeki yarım kubbe başlangıç seviyesi $(+13,95)$ ve kubbeli köşe birimlerin yükseklikleri bulunur. [F] Harimin kıble yönünde dıştan toplam ölçüsü $(30,05$ m) ile giriş sahanlığı (-0,96 m) ve kübik kitlenin üst noktası arasındaki yüksekliği (18,56 m) çevreleyen dikdörtgenin en / boy oranı 1,61'dir. [G] Kubbeyi taşıyan kemerlerin aksından giriş sahanlığı kotu ile başlayan dikdörtgenin kubbe ile ilişkisi $(26,90$ / 16,62) 1,62 oranı bulunur. [H] Harim yan sahın sivri kemer üst tepe noktası ile kubbenin örttüğü dörtgen alanın sınırladığı hacimde en / boy ilişkisi $(9,83$ / 6,07 m) 1,61 oranı bulunur. Yan cepheler ayrıca incelenmiştir. [I] Son cemaat yeri revakı yan kanatlarda kubbe başlangıç seviyesi (kemer tepe noktası), kuzey beden duvarı ve sütunlar üzerindeki duvar dış yüzeyi ile belirtilen dikdörtgenin boyutları arasındaki ilişki (9,28 / 5,73 m) 1,62 oranı bulunur.

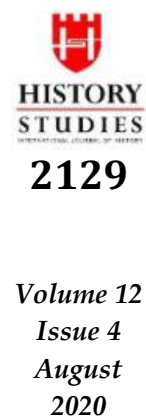

2020

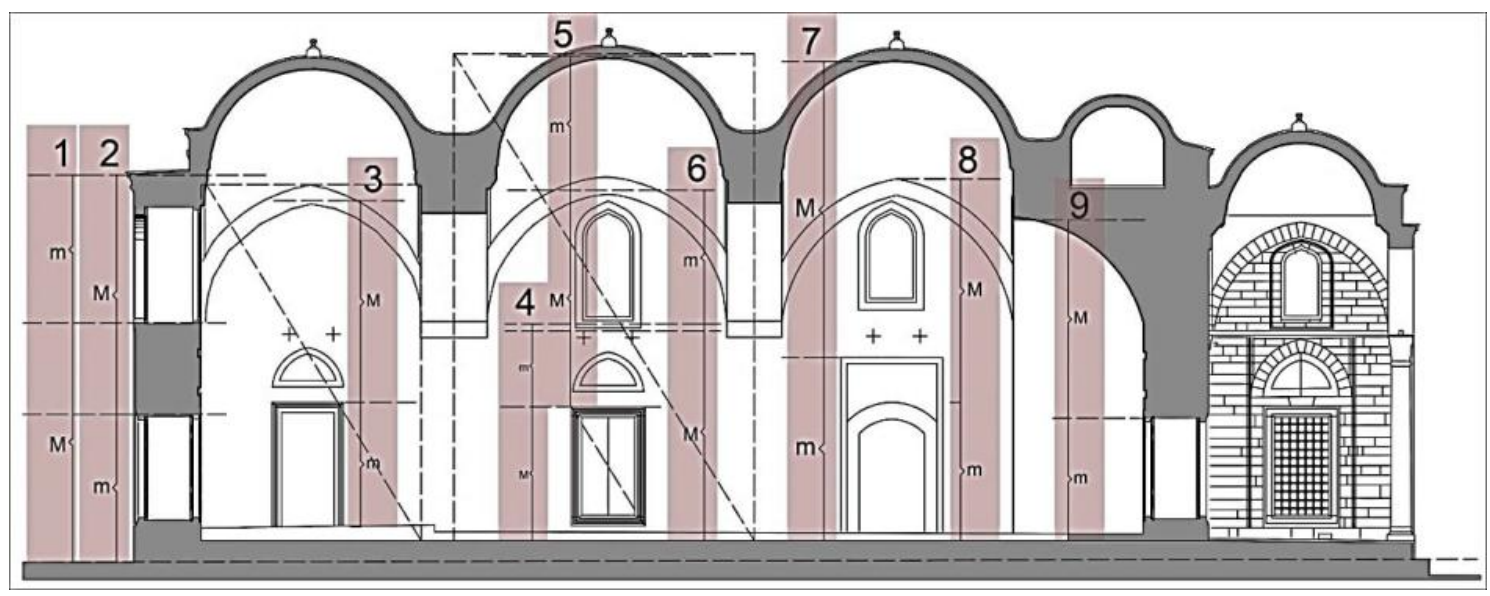

Şekil 5. Konya Sultan Selim Camii iç mekân batı cephesinde oran araştırması $(M / m=1,618)$

Konya Sultan Selim Camii iç mekân batı cephesinde oran araştırması, [1] Yan cephede zeminden $(-1,05)$ saçak silmesine $(+9,85)$ tüm yükseklik $(10,90 \mathrm{~m})$ altın oranda kesildiğinde bulunan açıklık başlangıç noktaları: Üst pencere boşluğu altı kotu $(+5,62)$ [2] Yan cephede tüm yükseklik $(10,90 \mathrm{~m})$ altın oranda kesildiğinde bulunan açıklık başlangıç noktaları: Alt pencere boşluğu üst kotu $(+3,05)$. [3] Dikdörtgen pencere sövesi üst kotu $(+3,43)$ ve üstündeki sivri kemer boşluğu tepe noktasının zeminden yükseklikleri $(+8,96)$ arasındaki ilişki $(8,96 / 5,53 \mathrm{~m}=1,62)$ [4] Zemin kat dikdörtgen açıklıklı mermer söveli pencere üst kotu ile üzerindeki pencere boşluğunun zeminden yükseklikleri arasındaki ilişki $(3,73 / 2,31 \mathrm{~m}=1,62)$ [5] Zemin kat dikdörtgen söveli pencere üst kotu ile kubbeye kadar olan yükseklik altın oranda bölündüğ̈ takdirde bulunan hatta kemerin tepe noktası bulunur. $(6,05 / 3,73 \mathrm{~m}=$ 1,62) [6] Zeminden sivri kemer tepe noktasına olan mesafenin altın oranda bölünmesi ile bulunan kesim noktasında pencere boşluğunun başlama hattı bulunur. $(6,05 / 3,73 \mathrm{~m}=1,62)$ [7] Zeminden kubbe kilit taşına tüm ölçü ile yan giriş kapıları üst kotu arasındaki ilişki $(8,27 / 5,11 \mathrm{~m}=1,62)$ [8] Yan giriş kapısı basık kemeri üst kotu ile sivri kemer üst kotu arasındaki ilişki $(6,24$ / 3,85 m = 1,62) (Orta hücrede görülen altın dikdörtgen kubbe kasnağ ile taşıyıcı aksları üzerindedir.) [9] Kuzey beden duvarındaki eyvan bölümü tepe noktası $(+8,57)$ ile zemin arasındaki mesafe $(9,00 \mathrm{~m})$ altın kesime göre bölündüğunde pencere açıklığının üst sınırı olan $(+2,99)$ kotu bulunur. $(5,56 /$ $3,44=1,62)$ 

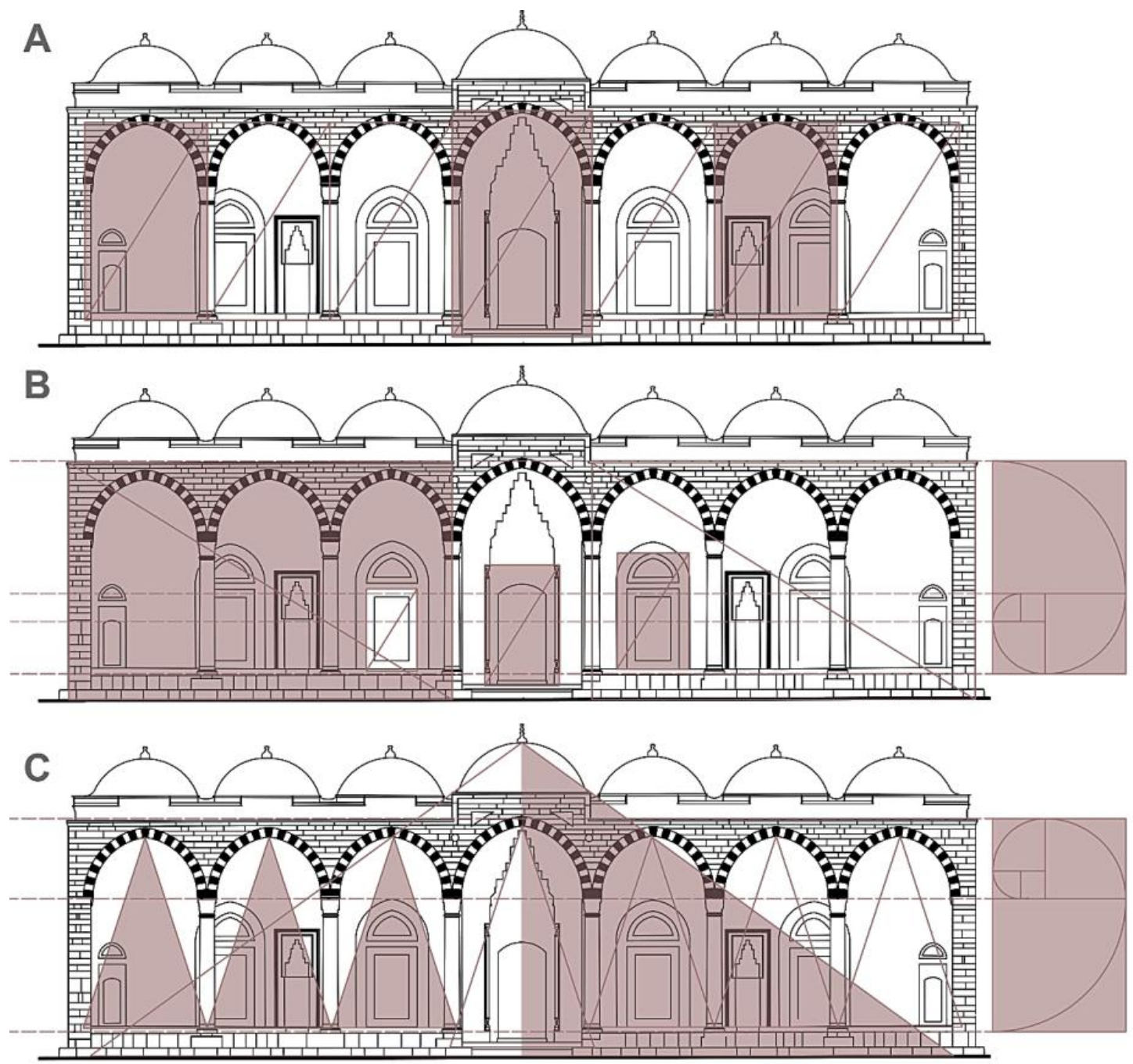

Volume 12

Issue 4

August

2020

\section{Şekil 6. Konya Sultan Selim Camii son cemaat yeri cephesinde oran araştırması}

Konya Sultan Selim Camii son cemaat yeri, [1] Sütun aksları, zemin ve kemer boşluğu tepe noktası arasında çizilen altın dikdörtgenler (A), Sağ ve sol kanatta tekrar etmektedir. $(8,10 / 5,05 \mathrm{~m}=1,60)$ [2] Cümle kapıs1 aksındaki hücrede zemin, kemer boşluğu tepe noktası ve sütun aksları arasında çizilen (A) dikdörtgenin boyutları (9,26 / 5,78 m = 1,61) [3] Sağ ve sol kanattaki üçer kemerli bölümlerin tümünü içine alan dikdörtgenler (B), Saçak kotu $(+8,39 \mathrm{~m})$ ve cümle kapısındaki dış kot $(-1,35 \mathrm{~m})(15,83 / 9,74 \mathrm{~m}=1,62)$ [4] Dikdörtgen açıklıklı mermer söveli pencerelerin (B) dış ölçüsü $(3,32 / 2,10 \mathrm{~m}=1,59)$ [5] Altın üçgenler (C), Sütun aksları, sütun altı ve kemer boşluğu tepe noktası arasında (Taban açıları eşit ve $72^{\circ}$ derece olan üçgenin kenarları arasında 1,618 oranı vardır.) $(8,28 / 5,12 \mathrm{~m}=1,62)$ [6] Altın üçgen $(\mathrm{C})$, Cephe boyunca devam eden hat ile orta kubbe tepe noktası arasında (Taban açıları eşit ve $36^{\circ}$ olan üçgenin kenarları arasında 1,618 oranı vardır.) [7] Son cemaat yeri yan kanat zemin kotu (-0,33 m) ile saçak kotu (+8,42 m)arasındaki mesafe $(8,75 \mathrm{~m})$ altın kesimle bölündüğünde 5,35 $\mathrm{m}$ kemer üzengi seviyesine ulaşı1ır. (C, Sağ başta) $(8,75 / 5,35 \mathrm{~cm}=1,63)$ [8] Aynı altın dikdörtgen ters kullanılır ise; $(3,40 \mathrm{~m})$ duvar içinde zemin kat pencere boşluğunun üst sınırı olan $+2,98 \mathrm{~m}$ kotuna ulaşılır. (B, Sağ başta) $(5,35$ / 3,35 m = 1,60) 


\section{4. İstanbul Sultan Selim Camii Biçim Özellikleri ve Müellif Sanatçı Konusu}

İstanbul Sultan Selim Camii tabhaneli camilerin son örneğidir ve 16. yüzyıl ilk çeyreğinde Sultan Süleyman tarafından babası adına o dönemin mimarbaşı olması sebebiyle Alâeddin Ali Bey’e yaptırılmış olduğu iddia edilmiştir. ${ }^{33} \mathrm{Bu}$ sınırlı bilgi birçok yazar tarafından tutarsız bulunmakla birlikte Alâeddin Ali Bey (Acem Ali'si) hakkındakı yeni bulgular tutarsızlığın giderilmesini sağlarken bu çalışmada ortaya konan tasarım yaklaşımı benzerliğini de açıklar niteliktedir. Kuban, İstanbul Yavuz Sultan Selim Camii müellifi konusuna değindiği yazısında eserin mimarının belli olmadığını belirtir. ${ }^{34}$ Tahsin Öz tarafından öne sürülen Acem Ali ismini ise ikna edici bulmadığını ifade eden Kuban, İran seferinden gelirken getirilmiş İranlı bir mimarın Edirne'deki bir camiyi örnek alarak İstanbul'da yeni bir cami yapması fikrinin doğru olamayacağını iddia etmektedir. ${ }^{35}$ Aynı şekilde Acem Ali ismi ile ilgili eski bilinenlere dayanarak Aslanapa da benzer şekilde külliye mimarı olduğu ileri sürülen ve Yavuz Sultan Selim'in Çaldıran savaşından sonra İstanbul'a getirdiği bu kişinin Osmanlı mimari üslubunu bu kadar kısa süre içinde benimseyip böyle bir eser vücuda getirmesinin mümkün olmadığını söylemektedir. ${ }^{36}$

Yakın zamanda yayınlanmış bu konuyu irdeleyen bir çalışma bahsedilen kişi hakkındaki kafa karışıklığının sebeplerini açıklarken bilinenleri de özetlemektedir. ${ }^{37}$ Yazar kısaca 1503 1539 tarihleri arasında mimarlık yaptığ 1 bilinen Acem Ali'nin kaynaklarda sıkça tekrarlandığ 1 şekli ile Tebriz'den getirilen İranlı bir mimar olduğu şeklindeki bilginin ciddi bir veriye dayanmadığını, Yavuz Sultan Selim'in Tebriz seferinden çok önce Amasya'ya gelmiş olmasının daha güçlü bir ihtimal olduğunu söylemektedir. Otuz yıldan uzun bir zaman Osmanlı devleti için mimarlık ve başmimarlık yaparak klasik üslubun tekamülünde ve Sinan'ın yetişmesinde önemli rolü bulunan bu kişinin daha önceki yayınlarda benzer isimli kişiler sebebiyle yanlış değerlendirildiği anlaşılmaktadır. Burada yaptığımız gibi Edirne, Sinan öncesi İstanbul ve Sinan dönemi yapılarının tasarım özellikleri üzerinde durularak, yaklaşım benzerlikleri ve uygulama kararlarındaki ortaklıklar yoluyla mimarlar ocağının sürekliliği ve yapıların müellif sanatçıları konusundaki boşlukların da giderilmesine katkıda bulunulacaktır.

\section{1. İstanbul Sultan Selim Camii'nde Kullanılan Kemer Tipleri}

Büyük tek kubbeli yapının revaklı avlusu ve birer şerefeli iki minaresi bulunur. Camiye bitişik iki yan tarafta üçer sekili eyvanı ve dörden odası bulunan tabhane bölümleri ile yap1 Edirne Beyazıt Camii'ne benzemektedir. Yapının büyük kubbesi kalın beden duvarları içindeki kemerler tarafından taşınmaktadır. Harim 24,23 x 24,30 m (32 x 32 zira) ölçülerinde olup beden duvarları üç yönde 2,60 m (3,5 zira) kalınlıkta, kuzey yönünde ise teğetli sivri kemerlerin altındaki eyvanların 2,45 m derinliği ve 1,66 m duvar kalınlığı ile toplamda 4,10 m’ye (5,50 zira) ulaşmaktadır. Mihrap duvarında 2,93 m genişlikteki payandalar dışarıda 1,60

\footnotetext{
${ }^{33}$ İbrahim Aydın Yüksel, "Sultan Selim Camii ve Külliyesi”, TDVİA, C. 37, İstanbul 2009, s.513-516.

${ }^{34}$ Doğan Kuban, "Sultan Selim Külliyesi”, Dünden Bugüne İstanbul Ansiklopedisi, Kültür Bakanlığı ve Tarih Vakfı ortak yayın1, C.7, İstanbul 1994, s.62.

${ }^{35}$ Tahsin Öz, Istanbul Camileri, Ankara 1965, C.2, s.129-131.

${ }^{36}$ Oktay Aslanapa, Osmanlı Devri Mimarisi, İnk1lap Kitabevi, İstanbul 2004, s.184.

${ }^{37}$ Hüseyin Gürsel Bilmiş, “Acem Ali Kimdir? Osmanlı Dönemi Hassa Baş Mimarı Alaeddin Ali b. Abdullah'ın Kişiliği ve Mesleki Kimliği Üzerine Bir İnceleme”, MANAS Sosyal Araştırmalar Dergisi, C. 9, S. 2, Nisan 2020, s.1089-1100.
} 
m taşma yapmaktadır. Cami kitlesi dışarıdan doğu batı yönünde 29,42 m (39,00 zira), 16,70 x $18,55 \mathrm{~m}(22,00 \times 24,5$ zira $)$ boyutlarındaki tabhane bölümleri ile birlikte doğu batı aksında 63,10 m (83,00 zira) genişliktedir. Avlu kıble aksında 34,20 m (45,00 zira), diğer yönde 39,55 m (52,00 zira) genişliktedir ve çevreleyen duvarlar üç yönde 1,55 m (2,00 zira) kalınlıktadır. 18 sütun üzerine 22 hücreli şadırvan avlusunda cümle kapısı ve avlu kuzey giriş önündeki hücreler tonoz diğerleri kubbe ile örtülüdür. Avluyu çevreleyen revakların derinliği planda 5,67 m (7,50 zira) olduğundan açık alan 28,20 x 22,80 m (37 x 30 zira) ölçüsündedir. Avlu ile birlikte yapının kıble aksında boyu 68,40 m (90,00 zira) olmaktadır.

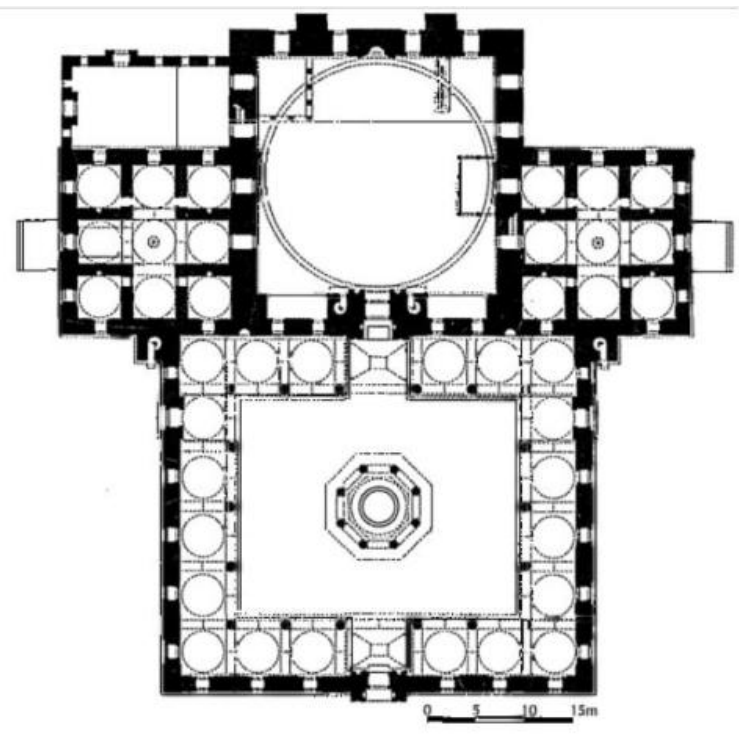

Şekil 7. İstanbul Sultan Selim Camii Plan (İ. Aydın Yüksel'den)

Harimde dört yönde duvarlar içinde büyük yuvarlak kemerler zeminden 6,40 m yükseklikte üzengi seviyesinden başlar, açıklığ $22,60 \mathrm{~m}$, kemer boşluğu tepe noktası 16,60 m ve kilit taş1 tepe noktası 17,65 m seviyesindedir. Kuzey yönünde cümle kapısının iki yanındaki 5,97 m açıklıklı teğetli sivri kemerler yine yuvarlak kemerin teğetli versiyonu olup, merkez hattından kemer boşluğu mesafesi $3,23 \mathrm{~m}$ ve toplamda kilit taş1 üst seviyesi zeminden 7,27 m yüksekliktedir. Cümle kapısının üzerindeki yuvarlak kemer ise 9,40 m açıklı̆ga sahip olup üzengi seviyesi zeminden $11,05 \mathrm{~m}$, en yüksek noktas1 16,10 m seviyesindedir. Müezzin mahfilinin üzerindeki teğetli kemer, avluda ikinci kat pencerelerinde de görüleceği gibi açıklığın üçe bölünmesi (1:3T) ile bulunan noktalardan çizilmiş $60^{\circ}$ 'lik yaylardan takye noktasına teğetler çizilerek kurulmuştur.

Dışarıda kıble doğrultusunda 5 , doğu - batı yönünde 4'er sivri kemer ile avluya açılan revaklar incelendiğinde 3 tip sivri kemerin kullanıldığ 1 görülmektedir. Cümle kapısı aksındaki pencî (1:5) sivri kemerin üzengi seviyesinde açıklığ $6,60 \mathrm{~m}$, merkez hattında açıklık 6,70 $\mathrm{m}$ ve en yüksek noktasının avlu zemininden yüksekliği 10,64 m bulunmuştur. Merkez hattı üzengi hattının $0,60 \mathrm{~m}$ kadar altındadır. Giriş aksını belirten beşlik sivri kemerin iki yanındaki ikişer kemer ise açıklı̆̆ın dörde bölünmesi ile kurulmuş (1:4) sivri kemerlerdir. 4,60 m açıklığa sahip kemerlerin kilit taşı üst kotu 9,84 m seviyesindedir. Orta hücrede sütun aksları arasındaki 
açıklık yan hücrelerden 2,00 m kadar daha geniştir ve kemer tepe noktaları arasına $0,80 \mathrm{~m}$ fark bulunur.

$\mathrm{Bu}$ cephenin tam karşısında avluya kuzeyden giriş yapılan kapının üzerinde yine ortada yükseltilmiş bir pencî (1:5) kemer bulunurken iki yanda (1:3) ve (1:4) merkezler arası uzaklık / açıklık oranına sahip iki merkezli sivri kemerler bulunmaktadır. Ortada sütun aksları arası açılılı 7,15 m, yanlarda $5,36 \mathrm{~m}$ ve $5,61 \mathrm{~m}$, ve merkezdeki kemerin tepe noktas $10,40 \mathrm{~m}$ yükseltilmiştir. Üzengi hattında $5,23 \mathrm{~m}$ açıklığa sahip beşlik kemerin merkez hattı başlangıç hattından $0,97 \mathrm{~m}$ aşağıdadır. (1:3) oranlı sivri kemerin açıklı̆̆ üzengi hattında 4,46 m, (1:4) oranlı sivri kemerinki 4,71 m olarak ölçülmektedir. Sütunlardan doğu, batı ve kuzey yönünde duvarlara atılan sivri kemerler de aynı (1:4) tipin 4,55 m açıklığa sahip versiyonudur. Son cemaat yerinde ise sütunlardan beden duvarlarına atılan kemerler (1:3) oranlıdır. Tepe noktasını hizalamak için kemerlerin üzengi seviyeleri ile merkez hatları farklı seviyelerde düzenlenmiştir. Avlunun doğu - batı cephelerinde giriş kapısı aksındaki hafifçe büyük açıklıklı olmakla birlikte tümü (1:5) oranlı dört sivri kemer bulunmaktadır. Yaklaşık 5,10 m açıklıklı kemerlerin tümünün üzengi seviyesi merkez hatının üzerinde olup kilit taşı tepe yüksekliğini hizalamak için $0,40-0,65 \mathrm{~m}$ gibi farklı miktarlarda ayarlama yapıldığı görülmektedir.

Caminin kuzey cephesinde bulunan zemin kattaki dikdörtgen açıklıklı mermer söveli pencerelerin üzerinde de $1,90 \mathrm{~m}$ açıklığa sahip pencî (1:5) sivri boşaltma kemerleri bulunmaktadır. Avlunun kuzey cephesindeki 6, yan cephelerindeki 5 zemin kat penceresi ve her üç avlu kapısının üzerindeki basık kemerin üzerinde bulunan sivri kemerlerin de benzer boyutlu pencî (1:5) kemerler oldukları görülmektedir. Avlunun kuzey, doğu ve batı cephelerinde zemindeki pencerelerin herbirinin aksında bulunan ikinci kat pencerelerin tümünün üst bölümü de (1:3) oranlı ve $0,90 \mathrm{~m}$ açıklıklı sivri kemerdir. Yine harimde her yönde zemin katta ve ikinci katta hünkâr mahfilinde bulunan pencereler üzerindeki boşaltma kemerleri de dışarıdaki kapıların üzerindeki aynı açıklığa sahip penci (1:5) kemerlerdir. Minare giriş kapısı üzerinde, tabhane cephelerinde ve iç mekânında da bu tipin kullanımı devam etmektedir.

\section{2. İstanbul Sultan Selim Camii’ne Oran Araştırması}

Yapının kitle kuruluşu incelendiğinde merkezde büyük tek kubbeyi taşıyan kübik harim bölümünün doğu ve batı yönlerinde kare planlı tabhane bölümleri ve kuzey yönünde enine geniş dikdörtgen biçimli şadırvan avlusu ile kurduğu ilişkilerde altın kesim yönteminin kullanıldığı hemen anlaşılmaktadır. (Şekil 8) Kare harim başlangıç noktası olarak alındığında buradan türetilen altın dikdörtgenler ile plan düzleminde tabhanenin (Şekil 8, A) ve avlunun (Şekil 8, C) sınırları belirlenmektedir. Üçüncü boyutta aynı şekilde bu üç birim arasındaki yükseklik ilişkileri altın kesime uygun olarak düzenlenmiştir. (Şekil 8, D, E, F) Daha önce de belirtildiği gibi, Konya Sultan Selim Camii ile İstanbul Yavuz Selim Camileri’nin tasarım yaklaşımlarındaki ortaklıkların kıyaslanması için nispeten karşılaştırma yapılmaya daha elverişli olan revak bölümleri detaylı olarak ele alınmıştır. Konya Sultan Selim Camii'nde hücrelerin ve tüm revakın biçimsel özellikleri ile İstanbul Sultan Selim Camii avlu revakları birlikte değerlendirildiğinde altın kesim, altın dikdörtgen ve üçgenlerin çok benzer şekillerde kullanılmış olduğu anlaşılmıştır. 
Özetle bu benzerliği tanımlamak gerekirse; son cemaat yeri ve avlu cephelerinin tümünde genişlik ile yükseklik arasındaki ilişki $36^{\circ}$ taban açısına sahip altın üçgenin yükseklik / taban oranına $(0,363)$ uygun şekilde düzenlenmiştir. Bu uygulama Konya Sultan Selim'de son cemaat yerinde ve İstanbul Sultan Selim de avlu revaklarının dört cephesinde olduğu gibi cami kitlesinin kuzey cephesinde de görülmektedir. (Şekil 9, A) Avlu cephelerinde hem açıklığa cephe veren hücreler hem tüm avlu beden duvarlarını baz alan toplam ölçü bu orana uygundur. İkinci olarak her iki yapıda hücrelerin her birinde yine altın üçgenin $72^{\circ}$ taban açısına sahip olan versiyonunun kullanılmış oldu görülmektedir. Yükseklik / taban oranı 1,538 olan bu üçgen son cemaat yeri ve avluda sivri kemer boşluğu tepe noktası ile açıklığı sınırlandıran sütunların aksları arasındaki boyut ilişkisini tanımlamaktadır.

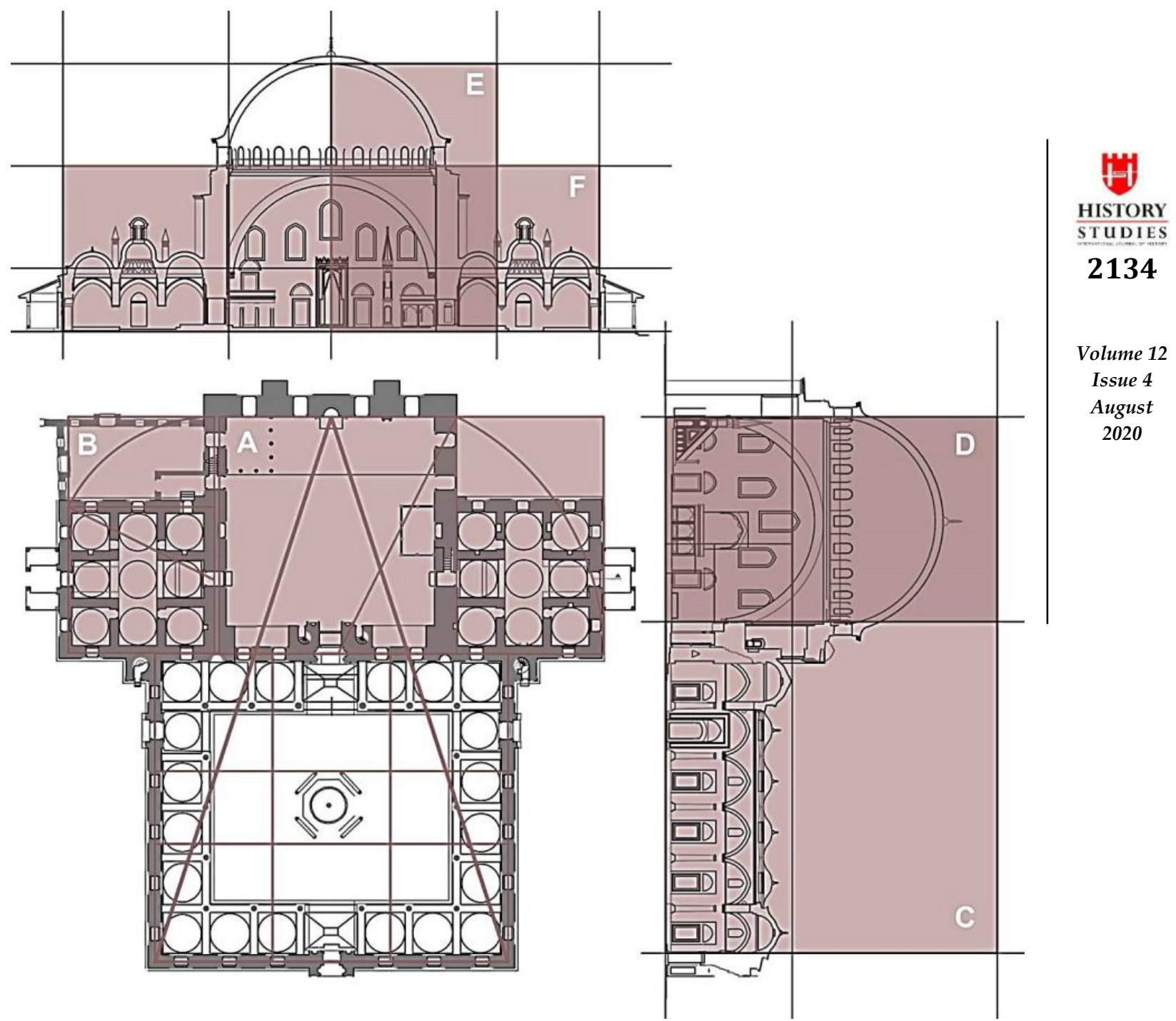

Şekil 8. İstanbul Sultan Selim Camii plan ve kesit düzlemlerinde oran araştırması (Rölöve VGM Arşivi) 
Yapıyı oluşturan bölümlerin boyutsal özelliklerinin nasıl birbirinden türetildiği ile ilgili olarak harim, tabhane ve avlunun zeminde ve üçüncü boyutta ilişkileri hakkında kabaca bir izlence oluşturmak gerekir ise; harim bölümünü başlangıç birimi olarak ele aldığımızda bu karenin [A] altın dikdörtgenine tamamlanması ile yatayda tabhane bölümünün sınırlarına ulaşılmaktadır. [B] Altın dikdörtgeni tabii olarak altın kesim kuralına göre bu dikdörtgen içerisinden çıkartılan kareden geriye yine aynı en / boy oranına sahip bir dörtgen oluşmaktadır. Avlunun plandaki sınırları harimin mihrap duvarı ortasından çizilen $36^{\circ}$ taban açısına sahip altın üçgen ile örtüşmektedir. Boy kesitte büyük altın dikdörtgen [C] harim ve avlu beden duvarlarını baz alır. Bu [C] dörtgenin içinden çıkartılan kare harim kuzey beden duvarını tutarken geriye [D] altın dikdörtgenini oluşturur. [D] Altın dikdörtgeninin yüksekliği altın kesim noktasından kesildiğinde cami giriş cephesinde son cemaat yeri revakı orta hücre tepe noktasını belirtmektedir. Kubbe kilit taşı yüksekliğini altın kesime böldügümüzde [E] kubbenin başlangıç seviyesi bulunur. Aynı dikdörtgen yatayda [F] tabhane dış konturunu göstermektedir. Kubbenin başlangıç seviyesi yine altın kesime göre bölündüğünde ise tabhanenin kubbe kasnağı yüksekliği bulunmaktadır.
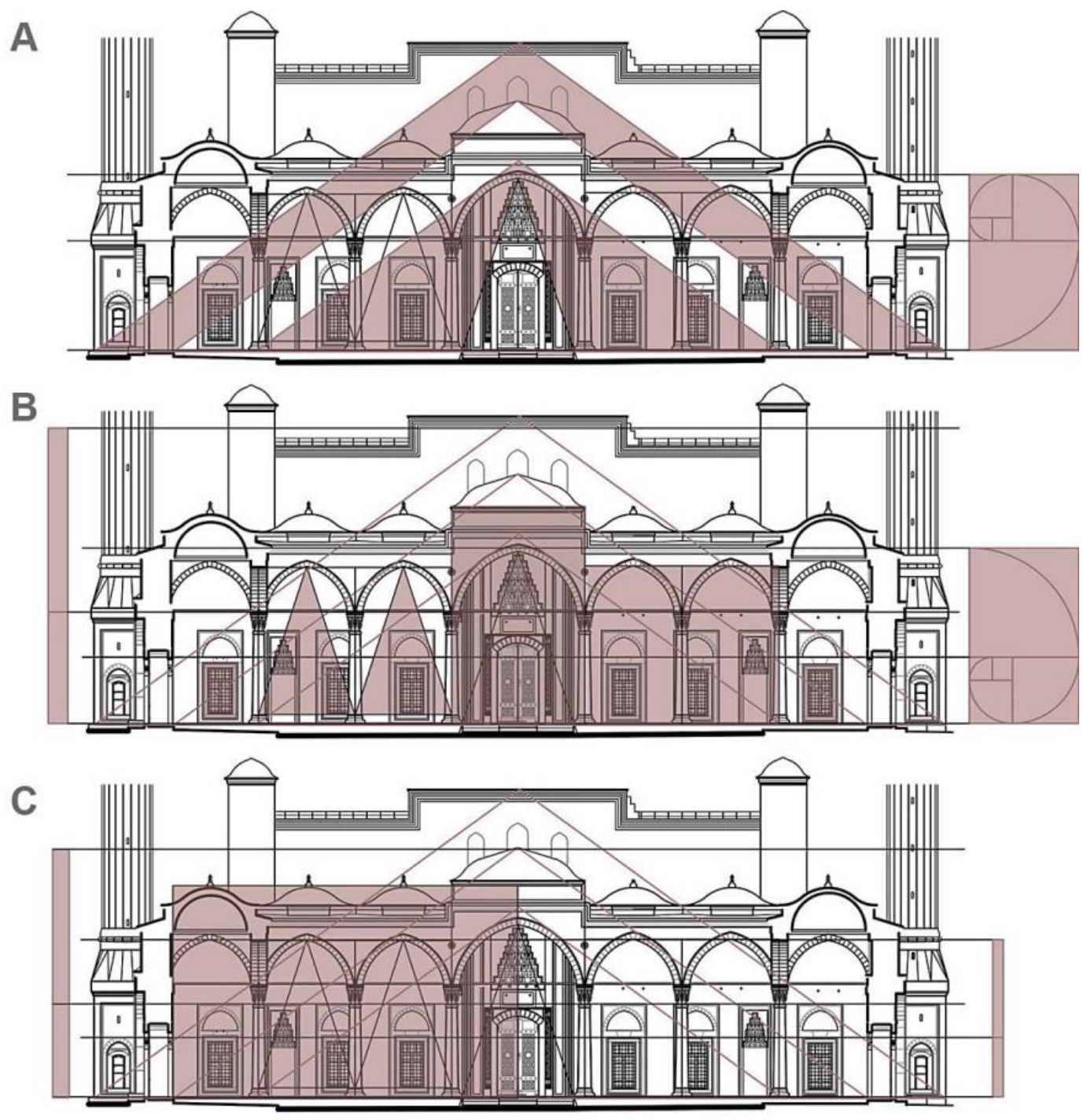

Şekil 9. İstanbul Sultan Selim Camii son cemaat yeri avlu cephesi (Rölöve: VGM Arşivi)

İstanbul Sultan Selim Camii Son Cemaat Yeri Kuzey Cephesi, Altın üçgen 1 (36 taban açıl1), Kuzey duvarı saçak silmesi $(+17,38)$ ile cümle kapısı eşik kotu $(+0,50)$ ve minare kaidesi arasında. Altın üçgen $2\left(36^{\circ}\right.$ taban açılı), 
Son cemaat revakı orta hücre tepe noktası $(+14,60)$, avlu yan girişleri zemin kotu $(+0,25)$ arasında. Altın üçgen 3 $\left(36^{\circ}\right.$ taban açı11), Son cemaat yeri orta hücre saçak silmesi $(+11,70)$, iki baştaki sütun aksları arasında, zemin kotu sütun başlangıcı $(+1,06)$. Altın üçgenler $4\left(72^{\circ}\right.$ taban açıl1), Yan kanatlarda sivri kemer boşluk üst noktası $(+9,36)$ ile sütun aksları $(+1,10)$ arasında. Altın üçgen $5\left(72^{\circ}\right.$ taban açı1ı), Orta hücre sivri kemer boşluğu tepe noktası $(+10,24)$ ile giriş sahanlığı $(+0,48)$ arasında. Altın dikdörtgen 1, Yan hücrelerde kemer boşluğu tepe noktası $(+9,36)$, sütun aksları ve yan kanat zemin kotu $(+0,57)$ arasında. Altın dikdörtgenler 2, Zemin kattaki dikdörtgen açıklığa sahip mermer söveli pencerelerin söve dış ölçüleri $(3,20 / 1,97 \mathrm{~m})$ arasındaki oran 1,62. Ayrıca tüm enine genişlik orta hücre saçağı hizasında iki eş altın dikdörtgenler (C) gösterilebilir. Altın dikdörtgen 3, Orta hücre saçak $(+12,66)$ kotu, zemin $(+0,57)$ ve sütun aksları arasında. Altın kesim 1, Revak saçak kotu $(+10,43)$ ile zemin kotu $(+0,57)$ altın kesime göre bölündüğünde sütun başlığ üst kotuna $(+6,70)$ ulaşılır. (Şekil A, sağ başta) Altın kesim 2 , Revak saçak kotu $(+10,43)$ ile zemin kotu $(+0,57)$ altın kesime göre bölündüğünde zemin kat dikdörtgen açıklıklı pencere üstündeki kemer üzengi kotuna $(+4,29)$ ulaşlır. (Şekil B, sağ başta) Altın kesim 3, Orta hücre üst örtüsü tepe kotu $(+14,60)$ ile cümle kapısı zemin kotu $(+0,40)$ altın kesime göre bölündüğünde sütun başlığı başlangıç seviyesi veya pencereleri çevreleyen bordür üst kotu bulunur. (Şekil C, sol başta) Altın kesim 4, Son cemaat zemin kotu $(+0,57)$ ile kemer boşluğu üst kotu $(+9,36)$ bölündüğünde dikdörtgen açıklıklı mermer söve üst kotu $(+3,93)$ bulunur. (Şekil C, sağ başta).
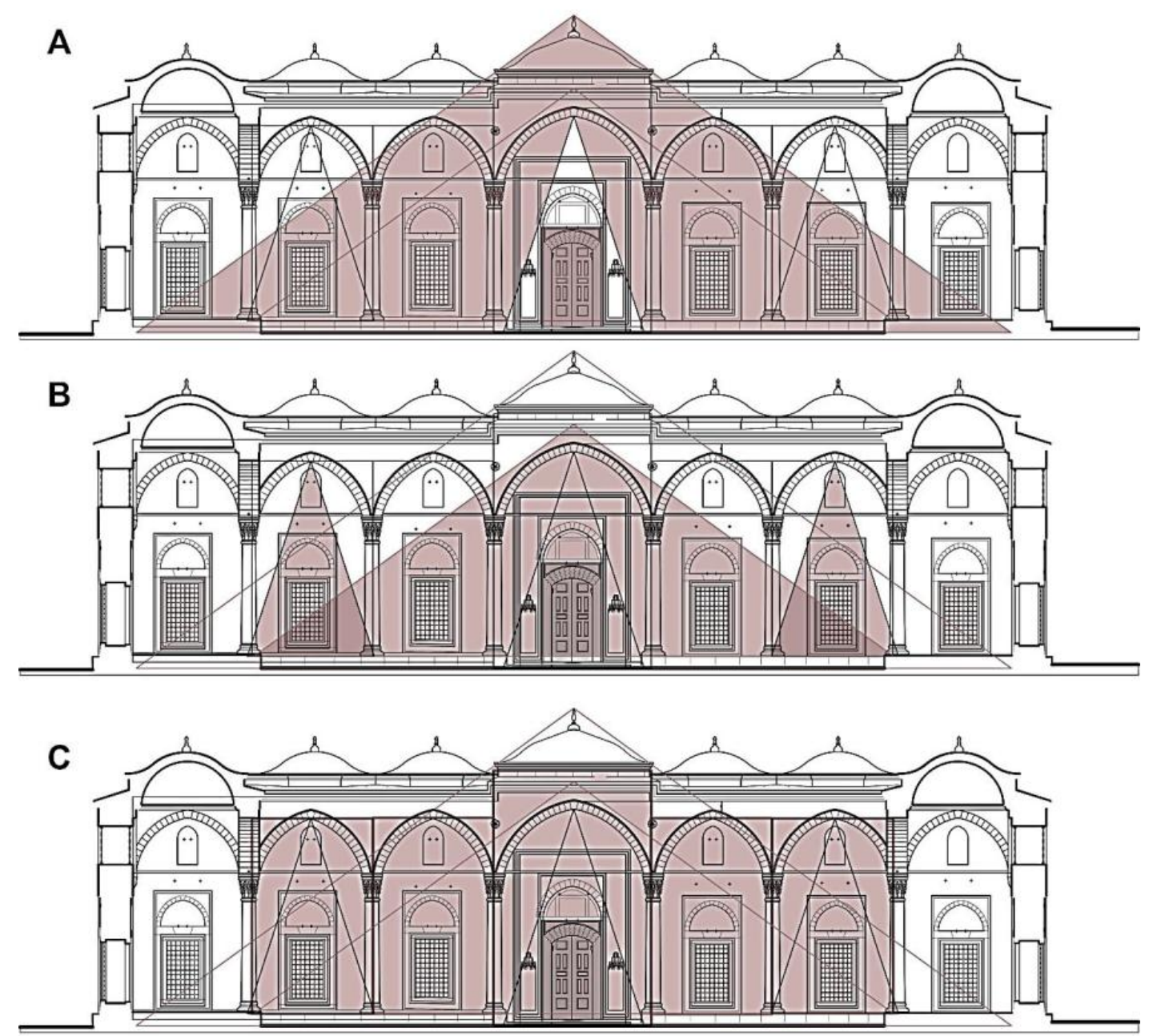

Şekil 10. İstanbul Sultan Selim Camii Avlusu Kuzey yönü revak cephesi (Rölöve: VGM Arşivi) 
İstanbul Sultan Selim Camii Avlusu Kuzey yönü revak cephesi, Altın üçgen 1 (36 taban açı11), Orta hücre tepe noktası $(+14,20)$, avluyu çevreleyen duvarlar ve zemin kotu $(+0,05)$ arasında (Şekil A). Altın üçgen $2\left(36^{\circ}\right.$ taban aç111), Orta hücre saçak silmesi $(+11,00)$, iki baştaki kolon aksları ve seki kotu $(+0,54)$ arasında (Şekil B). Altın üçgen $3\left(72^{\circ}\right.$ taban açı1ı), Orta hücre sivri kemer boşluğu tepe noktası $(+9,75)$ ile avlu zemin kotu $(+0,00)$ arasında (Şekil B). Altın üçgen $4\left(72^{\circ}\right.$ taban açı1ı), Yan kanatlarda sivri kemer boşluk üst noktası $(+9,36)$ ile sütun aksları ve seki kotu $(+0,54)$ arasında (Şekil B). Altın dikdörtgen 1, Orta hücre kasnak silmesi kotu $(+11,85)$, giriş sahanlığ1 $(+0,25)$ ve sütun aksları arasında (Şekil C). Altın dikdörtgen 2, Yan hücrelerde kemer boşluğu tepe noktası $(+9,36)$, sütun aksları ve yan kanat zemin kotu $(+0,54)$ arasında (Şekil C). Altın dikdörtgen 3, Zemin kattaki dikdörtgen açıklığa sahip mermer söveli pencerelerin söve dış ölçüleri $(3,20$ / 1,97m) arasındaki oran 1,62.

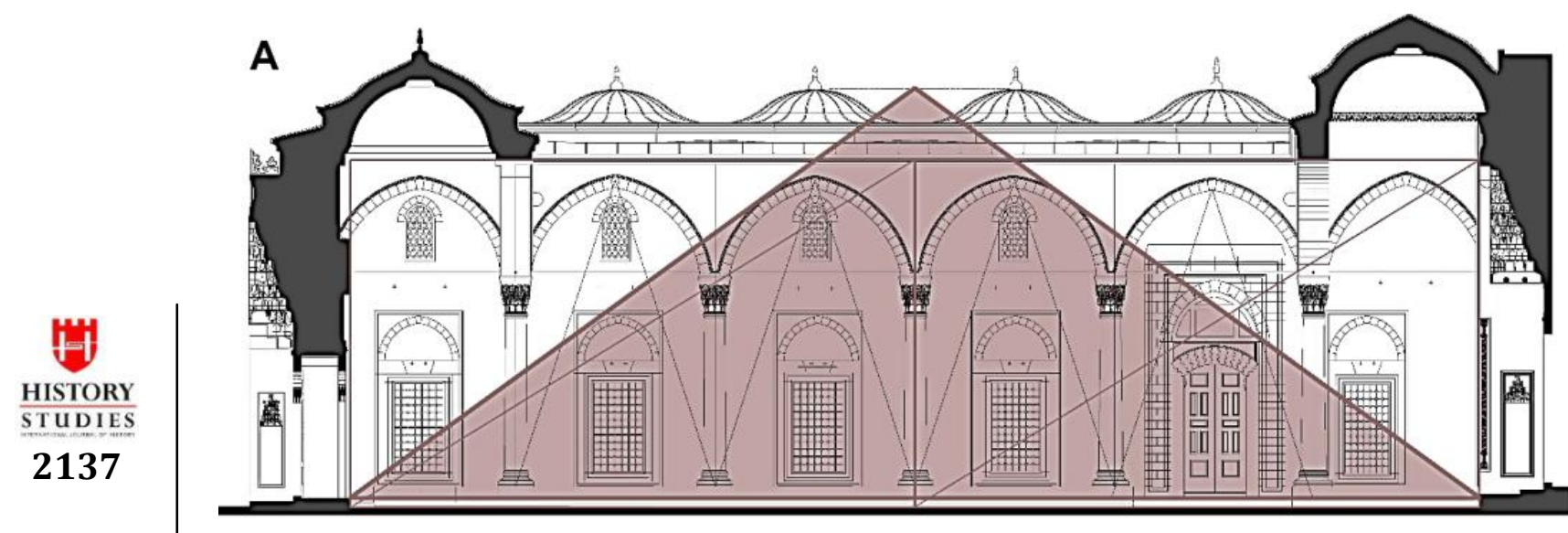

Volume 12

Issue 4

August

2020

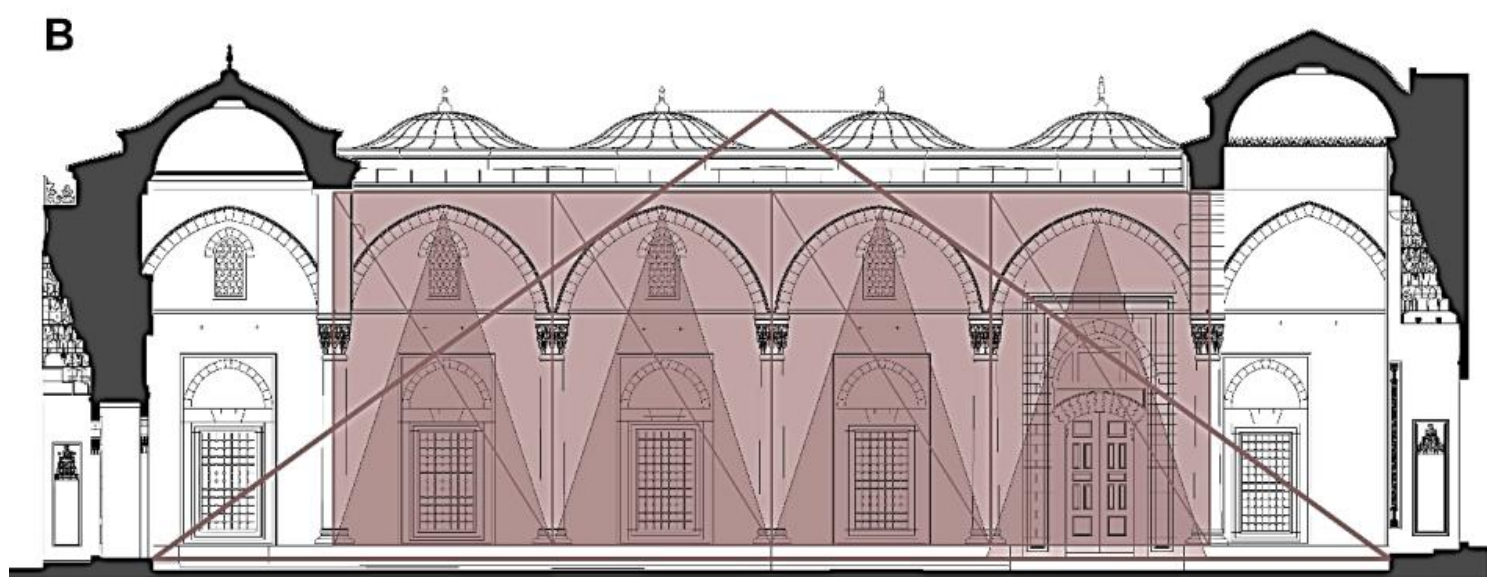

Şekil 11. İstanbul Sultan Selim Camii şadırvan avlusu Doğu cephesi (Rölöve: VGM Arşivi)

İstanbul Sultan Selim Camii şadırvan avlusu Doğu cephesi, Altın üçgen 1 (36 taban açılı), Revak üst örtü tepe noktası $(+12,35)$, avlu kuzey ve cami cümle kapısı eşikleri ile giriş sahanlığı zemin kotu $(+0,25)$ arasında. (Şekil A) Altın üçgenler 2 ( $72^{\circ}$ taban açıl1), Sivri kemer boşluk üst noktası $(+9,40)$ ile sütun aksları ve seki kotu $(+0,57)$ arasında. (Şekil B) Altın dikdörtgen 1, Kemer omzu duvar üst noktası $(+10,10)$, sütun aksları ve seki zemin kotu $(+0,57)$ arasında. (Şekil B) Altın dikdörtgen 2, Cami kuzey duvarından avlu kuzey duvarına tüm genişlik, zemin kotundan $(+0,00)$ saçak kotuna $(+10,44)$ iki eş boyutlu altın dikdörtgen ile bölünmektedir. (Şekil A) 


\section{Sonuç}

Bu çalışma başlangıçta Konya Sultan Selim Camii'nin müellifi konusunda karşılaşılan farklı görüşlerin, ayakta olan yapıların tasarım kararlarının incelenmesi yoluyla yeniden değerlendirilmesi fikrine dayanmaktadır. Konya şehir merkezinde ve Mevlevî dergâhı manzumesi içinde yer alan yapı hakkında ilk makalemizde yapının boyutları, kullanılan kemerlerin tipleri tespit edilmiş, Sinan devrinde İstanbul'da inşa edilen önemli camilerde kullanılan kemer tipleri ile karşılaştırılması yapılmıştı. Ayrıca konu ile ilgili farklı yazarların görüşleri ile bu iddiaların dayandığ tarihi metinlere değinilmişti. Yapının inşa tarihine ilişkin en makul iddialar zaman aralığı olarak Mimar Sinan'ın mimarbaşı olduğu döneme işaret etse de caminin üslup özellikleri bakımından Sinan'ın da hocası olan Hassa başmimarı Alâeddin Ali Bey'in yapıları arasında olduğu iddiası çalışmanın İstanbul'daki Sultan Selim Camii ile birlikte ele alınması gerekliliğini ortaya çıkarmıştır. Tasarım yaklaşımındaki ortaklıklar, kullanılan kemer tipleri yanında yatay ve düşey plan düzlemlerinde oran kullanımı konusunu gündeme getirmiştir. Böylece Konya Sultan Selim Camii çalışmasına paralel olarak İstanbul Sultan Selim Camii için de aynı tetkiklerin tümü yapılarak, yapının biçimsel özellikleri, kullanılan tüm kemerlerin boyutları ve tipleri, mekân ölçüleri ve cephelerde oran kullanımı başlıkları karşılaştırmaya temel olacak şekilde hazırlanmıştır. Bu doğrultuda çalışma ayakta olan yapıların biçim özellikleri üzerine devam ederken Acem Ali olarak da bilinen Alâeddin Ali Bey hakkında yakın zamana kadar yanlış bilinen, özellikle farklı kişilerin hayatlarının birbirine karıştırılması sebebiyle mimarlık tarihçileri tarafından tatmin edici bulunmayan meslek hayatı da bulgularımızı destekleyecek şekilde açıklanmıştır.

Özetlemek gerekirse; İstanbul Yavuz Sultan Selim Camii iç mekânında yuvarlak kemer, yuvarlak kemerin teğetli versiyonu ve penci kemer (1:5), son cemaat yeri ve avluda ise (1:3), (1:4) ve (1:5) oranlı sivri kemerlerin kullanıldığ görülmektedir. Konya Sultan Selim Camii’nde bu tiplerin ne olduğu konusunda önceki çalışmamızda iç mekânda yuvarlak ve pencî (1:5) kemer, son cemaat yeri revaklarında (1:7) oranlı sivri kemer kullanımı tespit edilmişti. Oran araştırması itibariyle Yavuz Sultan Selim Camii son cemaat yeri ve avlu revakları incelendiğinde ise Konya Sultan Selim Camii ile birçok tasarım benzer yaklaşımı olduğu görülmektedir. Revak cephelerinde bulunan kemerlerin tipleri, üzengi seviyeleri, merkez hatt1 seviyeleri, kilit taşı tepe noktaları ve kolon aksları ile avluyu sınırlandıran yüzeyler ve revak saçak kotu parametreleri temel alındığında altın kesim yönteminin ve buradan türetilen üçgen dörtgenlerin yapı bölümlerinin boyutlandırılmasında kullanıldığı görülmektedir.

İstanbul Yavuz Sultan Selim Camii'nde kullanıldığı tespit edilen kemer tiplerinin İstanbul'daki Mimar Sinan dönemi yapıları ile kısaca karşılaştırması yapıldığında; sonraki dönemde bu yapının aksine askı kemerlerinde yuvarlak kemere yakın iki merkezli kemer tipleri daha yaygındır. Zemin kattaki pencerelerin üzerinde pencî kemer burada olduğu gibi en yaygın kullanılan tip olmuştur. İçeride müezzin mahfilinin üzerinde ve avluda kullanılan (1:3) oranlı kemerin üst bölümü teğetli versiyonunu Eyüp Zal Mahmut Paşa hariminde ve Eminönü Rüstem Paşa Camii cephelerinde, Karagümrük Mesih Mehmet Paşa Camii avlusunda, sivri kemer versiyonunu ise Azapkapı Sokullu Mehmet Paşa Camii'nde zemin kat pencerelerinin üzerindeki boşaltma kemerlerinde, Süleymaniye Camii dış yan sofalarında, Kılıç Ali Paşa 
Camii giriş yönündeki mahfili taşıyan ayakların üzerinde görülmektedir. Yuvarlak kemer Haseki Camii son cemaat yerinde, Üsküdar Mihrimah Sultan Camii son cemaat yeri revaklarında, Şehzade Mehmet Camii'nde cephede, Eminönü Rüstem Paşa, Üsküdar Şemsi Paşa ve Kasımpaşa Piyale Paşa Camileri'nde cephede tespit edilmektedir. (1:4) oranlı sivri kemer Süleymaniye Camii avlusunda, Haseki, Üsküdar ve Edirnekap1 Mihrimah Sultan Camileri cephelerinde bulunmuş oldukça nadir bir tiptir. (1:5) oranlı penci kemerin tüm konumlarda yaygın kullanımı sebebiyle burada ayrıca detaylı listelenmemiştir. Ancak diğer (1:3), (1:4) oranlı sivri kemerler ile yuvarlak kemerin Mimar Sinan dönemi İstanbul'da inşa edilmiş 19 yapıda oldukça az tercih edilmiş olduğu görülmüştür. Nispeten daha dairesel olan, merkezler arası uzaklığı daha küçük (1:7), (1:9) gibi tiplerin tercih edildiği, kubbeyi taşıyan büyük kemerlerde dahi $(1: 11)$, (1:13) gibi iki merkezli tiplerin tercih edildiği ortaya çıkmaktadır. Ayrıca Yavuz Sultan Selim Camii'inde, avluda farklı açıklıklar üzerindeki kemerlerde üzengi seviyeleri ile merkezlerin bulunduğu hattın yukarı aşağı hareket ettirilmesi ile yan yana farklı kemer tiplerin kullanımının birlikte uygulandığı görülmektedir. Burada Sinan öncesi dönemin önemli yapılarından ilk etapta Alâeddin Ali Bey'in de inşasında yardımcı mimar olarak bulunduğu İstanbul Bayezid Camii'nin biçim özellikleri bakımından incelenerek kullanılan kemer tipleri ve oran konusunun tetkik edilmesi, bu sayede Osmanlı mimarlığında Sinan devrinde en olgun ürünlerini veren klasik üslubun gelişiminin izlenmesi de mümkün olacaktır.

Her iki yapıda ortak olan tasarım yaklaşımı, müellif sanatçı konusunda Konya Sultan Selim ile İstanbul Yavuz Sultan Selim Camileri’nin birlikte değerlendirilmesi gerektiğini göstermiştir. Buradan hareketle şu sorular gündeme gelmektedir. İlk olarak Konya Sultan Selim Camii yapım tarihi Mimar Sinan döneminin ortalarına rast geldiği halde bu yapının önceki dönem tasarım kararlarını sürdürmesini mümkün kılan şey nedir? İlk akla gelen iki ihtimalden birincisi yapının inşası için görevlendirilen Hassa mimarının Sinan öncesinde teşkilat içinde yetişmiş olduğu ve Alâeddin Ali Bey'in de icra ettiği yaklaşımı sürdürdügü olacaktır. İkinci olasılık yapının temel tasarım kararlarının daha önceden alınmış olduğu, yapının bu lokasyon için değilse bile tip olarak üretilmiş ve temsil düzeyinde modelinin ya da resminin önceden üretilmiş olduğudur. Nitekim Mevlevî dergâhı'na ilave edilen mescid bölümünün yapım tarihi de yeni bir cami yapımının ani bir karar ile gerçekleştirildiğini ve planlanan yapım işinin bekletilmediğini göstermektedir. Eğer yapının temel tasarım kararları teşkilat içinde mevcut olan bir katalog kapsamında saklanmış ve bu bağlamda kullanılması sonraki bir dönemde gerçekleşmiş ise, müellif mimar konusundaki bilinmezliğin temelinde yatan gerekçenin, Hassa Mimarları Ocağı'nın bu üretimlerinin anonim karaker taşıdığı şeklinde açıklanması mümkün olacaktır. Bu anonim karakter Sinan öncesi yapıların bir kısmının müellif sanatçılarının meçhul olduğu gerçeği ile de örtüşmektedir. Bununla birlikte ortaya çıkan resim, saray mimarları teşkilatının tek bir kişinin mesleki kariyeri şeklindeki yanlış okumadan kaynaklı anlayışın ötesinde, çok daha geniş bir kadro marifetiyle üretim yaptığını da hatırlatmaktadır. 


\section{Kaynakça}

\section{Arşiv Kaynakları}

Ankara Vakıflar Genel Müdürlüğü Arşivi, 475/7.

İstanbul Vakıflar 1. Bölge Müdürlüğü Arşivi, İstanbul I Numaralı Kültür ve Tabiat Varlıklarını Koruma Bölge Kurulu onaylı Yavuz Sultan Selim Camii Rölöve Projesi (2008).

Konya Vakıflar Bölge Müdürlüğü Arşivi, Konya Kültür Varlıklarını Koruma Kurulu onaylı Konya Sultan Selim Camii Restorasyon Projesi (2014).

\section{Yayınlanmış Eserler}

ALBERTI, Leon Batista, The Ten Books of Architecture, 1755 Leoni Edition, Dover Publications Inc., New York 1986.

ÂLÎ MUSTAFA EFENDİ, Künhü'l-Ahbâr, Nuruosmaniye Kütüphanesi, Ms.3409.

ASLANAPA, Oktay, Osmanlı Devri Mimarisi, İnkılap Yayınları, İstanbul 2004.

BERGIL, Mehmet Suat, Altın Oran, Arkeoloji ve Sanat Yayınlan, lstanbul 1993.

BİLMIŞ, Hüseyin Gürsel, “Acem Ali Kimdir? Osmanlı Dönemi Hassa Baş Mimarı Alaeddin Ali b. Abdullah’ın Kişiliği ve Mesleki Kimliği Üzerine Bir İnceleme”, MANAS Sosyal Araştırmalar Dergisi, C.9, S.2, Nisan 2020, s.1089-1100.

DÜNDAR, Abdülkadir, “Karapınar Sultan Selim Câmii’nin Mimarı Hakkında Yeni Bir Kayıt ve Bazı Mülahazalar", Türkiye Büyük Millet Meclisi'nin Açılışının 80. Yıldönümü Karapınar Sempozyumu, 2000, s.165-174.

EYİCE, Semavi, “Cami”, Türkiye Diyanet Vakfi İslam Ansiklopedisi, C.7, İstanbul 1993, s.5690.

HAMMER-PURGSTALL, Joseph Von, Devlet-i Osmâniyye Târihi, trc. Mehmed Atâ. İstanbul, 1329-1337.

KONYALI, İbrahim Hakkı, Âbideleri ve Kitâbeleri ile Konya Tarihi, Yeni Kitap Basımevi, Konya 1964.

KUBAN, Doğan, "Yavuz Selim Camii”, Dünden Bugüne İstanbul Ansiklopedisi, Kültür Bakanlığı ve Tarih Vakfı Ortak Yayını, C.7, İstanbul 1994, s.62-63.

KUBAN, Doğan, Mimarlık Kavramları, Yapı Endüstri Merkezi Yayınları, İstanbul 1990.

KURAN, Aptullah, Mimar Sinan, Hürriyet Vakfı Yayınları, İstanbul 1986.

KÜÇÜKDAĞ, Yusuf, "Sultan Selim Camii ve Külliyesi”, Türkiye Diyanet Vakfi İslam Ansiklopedisi, C.37, İstanbul 2009, s.516-517.

KÜÇÜKDAĞ, Yusuf, Karapınar Sultan Selim Külliyesi, Karapınar Belediyesi Yayını, Konya 1997. 
LE CORBUSIER, (Charles Edouard Jeanneret), The Modulor and Modulor 2, Birkhäuser, Basel 2000.

MASIERO, Roberto, Mimaride Estetik, Dost Kitabevi Yayınları, Ankara 2006.

MÜLAYİM, Selçuk, “Ahenk”, Türkiye Diyanet Vakfi İslam Ansiklopedisi, C.1, İstanbul 1988, s.523-524.

NECIPOĞLU, Gülru, Sinan Çă̆g: Osmanlı İmparatorluğu'nda Mimari Kültür, İstanbul Bilgi Üniversitesi Yayınları, İstanbul 2013.

NEUFERT, Ernst, Yapı Tasarımı, Kelaynak Yayınevi, Ankara 1983.

ÖZ, Tahsin, İstanbul Camileri, Türk Tarih Kurumu, Ankara 1965.

ÖZYALVAÇ, Ali Naci, İstanbul'da Mimar Sinan Camilerinde Sivri Kemer Biçimlenişleri, (Yayımlanmamış Doktora Tezi, Yıldız Teknik Üniversitesi Fen Bilimleri Enstitüsü), İstanbul, 2017.

PEKER, Ali Uzay, “Altın Oran ve Mimarlık: Efsane ve Gerçekler: Mimarlık Altın Oran ilişkisi üzerine kısa bir yazı”, Boğaziçi Dergisi, Boğaziçi Üniversitesi Mezunlar Derneği, S.231, 2017, s.46-47.

SÖNMEZ, Zeki, “Acem Ali” Türkiye Diyanet Vakfi İslam Ansiklopedisi, C. 1, İstanbul 1988, s.322.

Volume 12

SÖZEN, Metin - TANYELİ, Uğur, Sanat Kavram ve Terimleri Sözlüğü, İnkılap Kitbabevi, İstanbul 1992.

TUNALI, İsmail, Grek Estetik'i, Remzi Kitabevi, İstanbul 1983.

TUNCER, Nüket, Klasik Dönem Osmanlı Mimarisinde İç Mekân ve Cephelerde Oran, (Yayımlanmamış Doktora Tezi, Yıldız Teknik Üniversitesi Fen Bilimleri Enstitüsü), İstanbul 1996.

UZLUK, Şahabeddin, “İstanbul'daki Eski Fatih Camii’nin Bir Benzeri Konya'da Selimiye Camii”, Vakıflar Dergisi, S.9, Ankara 1971, s.173-181.

ÜNSAL, Behçet, Mimari Tarihi, İ.D.M.M.A. Yayınları, İstanbul 1973.

YETKIN, Suut Kemal, Estetik, Remzi Kitabevi, İstanbul 1947.

YÜKSEL, İbrahim Aydın, "Sultan Selim Camii ve Külliyesi”, Türkiye Diyanet Vakfi İslam Ansiklopedisi, C. 37, İstanbul 2009, s.513-516. 